\title{
Apatite: A new redox proxy for silicic magmas?
}

2

A.J. Miles ${ }^{\mathrm{a}, *}$, C.M. Graham ${ }^{\mathrm{a}}$, C.J. Hawkesworth ${ }^{\mathrm{b}}$, M.R. Gillespie ${ }^{\mathrm{c}}$, R.W. Hinton ${ }^{\mathrm{a}}$, G.D.

Bromiley $^{\mathrm{a}}$ and EMMAC ${ }^{\mathrm{d}}$

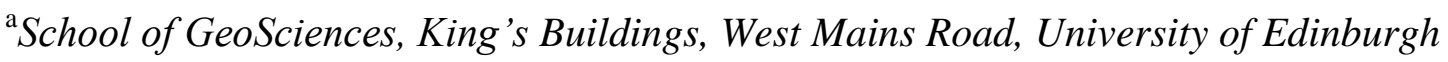
Edinburgh, EH9 3JW, UK

${ }^{\mathrm{b}}$ School of Geography and Geosciences, University of St Andrews, North Street, St Andrews, KY16 9AL, UK

${ }^{\mathrm{c}}$ British Geological Survey' Murchison House, West Mains Road, Edinburgh, EH9 3LA, UK

${ }^{d}$ Edinburgh Materials and Micro-Analysis Centre, School of GeoSciences, King's Buildings, West Mains Road, University of Edinburgh, Edinburgh, EH9 3JW, UK

*Current address: School of Geology, Geography and the Environment, Penrhyn Road,

(0)20 84172492

Abstract

The oxidation states of magmas provide valuable information about the release and speciation of volatile elements during volcanic eruptions, metallogenesis, source rock compositions, open system magmatic processes, tectonic settings and potentially titanium (Ti) activity in chemical systems used for Ti-dependent geothermometers and geobarometers. In this paper we explore the use of $\mathrm{Mn}$ in apatite as an oxybarometer in intermediate and silicic igneous rocks. Increased $\mathrm{Mn}$ concentrations in apatite in granitic rocks from the zoned Criffell 
granitic pluton (southern Scotland) correlate with decreasing $\mathrm{Fe}_{2} \mathrm{O}_{3}\left(\mathrm{Fe}^{3+}\right)$ and $\mathrm{Mn}$ in the whole-rock and likely reflect increased $\mathrm{Mn}^{2+} / \mathrm{Mn}^{3+}$ and greater compatibility of $\mathrm{Mn}^{2+}$ relative to $\mathrm{Mn}^{3+}$ in apatite under reduced conditions. $\mathrm{Fe}^{3+} / \mathrm{Fe}^{2+}$ ratios in biotites have previously been used to calculate oxygen fugacities $\left(f \mathrm{O}_{2}\right)$ in the outer zone granodiorites and inner zone granites where redox conditions have been shown to change from close to the magnetitehematite buffer to close to the nickel-nickel oxide buffer respectively (Stephens et al., 1985). This trend is apparent in apatite Mn concentrations from a range of intermediate to silicic volcanic rocks that exhibit varying redox states and are shown to vary linearly and negatively with $\log f \mathrm{O}_{2}$, such that

$\log f \mathrm{O}_{2}=-0.0022( \pm 0.0003) \mathrm{Mn}(\mathrm{ppm})-9.75( \pm 0.46)$

Variations in the Mn concentration of apatites appear to be largely independent of differences in the Mn concentration of the melt. Apatite Mn concentrations may therefore provide an independent oxybarometer that is amenable to experimental calibration, with major relevance to studies on detrital mineral suites, particularly those containing a record of early Earth redox conditions, and on the climatic impact of historic volcanic eruptions.

\section{Introduction}

Redox conditions play a pivotal role in determining the metallogenic properties of plutonic bodies (Ishihara, 1977, 1981; Belvin, 2004) and they control the molecular speciation of volcanic gases containing sulphur, carbon and hydrogen exsolved on eruption (e.g. Scaillet et al., 1998). These volatile gasses in turn control magma dynamics (e.g. Huppert and Woods, 2002; Gonnerman and Manga, 2003) and the composition and evolution of the Earth's 
atmosphere (Kasting et al., 1993; Trail et al., 2011; Scaillet and Gaillard, 2011; Binder and Keppler, 2011). For example, sulphur is thought to partition preferentially into fluid phases relative to silicate melts under oxidising conditions, resulting in greater sulphur emissions from explosive eruptions of oxidised silicic magmas relative to eruptions of reduced magmas (Scaillett et al., 1998). The eruption of oxidised silicic magmas is therefore likely to have a significantly greater climatic impact (Robock, 2000) than those of reduced magmas. Furthermore, it is becoming increasingly apparent that redox conditions strongly influence titanium activity $\left(\mathrm{a}_{\mathrm{TiO} 2}\right)$ in chemical systems, to the extent that it has recently been suggested that redox state may be used as proxy for titanium activity (Ghiorso and Gualda, 2013). Constraining redox conditions may therefore be important for the successful application of $\mathrm{a}_{\mathrm{TiO} 2}$-dependent geothermometers and geobarometers (Wark and Watson, 2006; Ferry and Watson, 2007; Hayden et al. 2008; Thomas et al. 2010; Ghiorso and Gualda, 2013).

60

Redox states of magmas and their variations reflect their sources and tectonic settings and also provide important constraints on their ascent and evolution (e.g. Ishihara, 2004). It is widely accepted that calc-alkaline magmas, found mainly around active subduction zones, are more oxidised than their tholeiitic counterparts (Gill, 1981; Arculus, 2003; Carmichael, 1991; Kelly and Cottrell, 2009; Lee et al., 2010). This is reflected in Fe depletion during differentiation of calc-alkaline magmas that results from the stabilisation of $\mathrm{Fe}^{3+}$-bearing oxide minerals under more oxidising conditions (Gill, 1981).

68

Quantitative estimates of redox conditions are calculated using oxygen fugacity $\left(\mathrm{O}_{2}\right)-\mathrm{a}$ measure of the availability and capacity of oxygen to participate in reactions of minerals and fluids. The higher oxygen fugacities of calc-alkaline magmas may be inherited from source 
achieved by redox reactions during degassing (Holloway et al., 2004; Burgisser and Scaillet, 2007). Estimating the $\mathrm{fO}_{2}$ conditions of magmas has traditionally relied on the measured $\mathrm{Fe}^{2+} / \mathrm{Fe}^{3+}$ ratios of magmatic glasses and mineral phases (Carmichael and Ghiorso 1990). The effects of alteration can reduce the reliability of results, but they can to some extent be overcome by examining heterovalent transition elements such as $\mathrm{V}$ and $\mathrm{Cr}$ that are generally immobile during alteration, but whose partitioning is redox-sensitive (Canil, 1997).

Accessory minerals provide a particularly robust record of magma conditions, and their frequent preservation in the sedimentary record as detrital minerals means they can be used to document the formation and evolution of magmas now lost from the geological record. A method of constraining magma redox conditions from detrital minerals could provide an important new tool for examining Earth evolution processes. The concentrations of redox sensitive elements such as $\mathrm{Fe}, \mathrm{Mn}, \mathrm{Ce}$ and $\mathrm{Eu}$ in accessory minerals offer great potential in obtaining reliable estimates of redox conditions. For example Ce anomalies in zircon have recently been experimentally calibrated at varying $f \mathrm{O}_{2}$ conditions by Trail et al., (2011) in order to estimate the oxidation state of Hadean magmas.

In this paper, we have evaluated the redox conditions in granitic rocks from the post-

91 Caledonian Criffell pluton in southern Scotland using Ce anomalies in zircon and $\mathrm{Fe}^{3+} / \mathrm{Fe}^{2+}$ ratios in biotite (Stephens et al., 1985). The former method is shown to result in large uncertainties in calculated $f \mathrm{O}_{2}$ values. We investigate the use of $\mathrm{Mn}$ concentrations in coexisting apatites to record changing redox conditions in this pluton. We also examine the capacity of Mn concentrations in apatites to provide a reliable proxy for redox conditions in a range of volcanic rocks where independent estimates of redox conditions are available.

97 Apatite Mn concentrations may permit robust estimates of redox conditions in a range of 
magma compositions, and they have great potential for constraining redox conditions on the early Earth through application to detrital minerals. Reliable estimates of the redox conditions of historic volcanic eruptions may also enable better estimates of their climatic impact.

\section{The Criffell pluton}

The Criffell pluton is one of a large number of post-Caledonian granitic plutons in northern parts of the United Kingdom. The pluton was emplaced at $410 \mathrm{Ma}$ (Miles et al., 2013b) into low-grade wackes and pelites of Llandovery to Wenlock age in the Southern Uplands accretionary prism in southern Scotland (Fig. 1). The pluton is normally zoned (Stephens et al., 1980, 1985), with outer zones (1 and 2$)$ of metaluminous granodiorite ( 58 wt $\left.\% \mathrm{SiO}_{2}\right)$, a transition zone (3), and inner zones (4 and 5) of peraluminous granite $\left(\sim 72\right.$ wt $\left.\% \mathrm{SiO}_{2}\right)$. Granodiorite samples contain primary hornblende (with occasional cores of clinopyroxene), biotite, plagioclase, potassium feldspar, quartz and accessory sphene, zircon, apatite, allanite and magnetite. Granite samples contain primary muscovite and small amounts of monazite but lack hornblende, sphene and the abundant zircon and magnetite that characterise the granodiorites. The small amounts of magnetite in the most silicic zone containing zircon (Zone 4) show evidence of trellis oxidation-exsolution (Fig. 2). This is thought to reflect exsolution of magnetite and ulvospinel, with subsequent oxidation of ulvospinel to ilmenite (Haggerty, 1991).

A general trend of decreasing $\mathrm{Fe}_{2} \mathrm{O}_{3}\left(\mathrm{Fe}^{3+}\right)$ with indices of differentiation (e.g. $\left.\mathrm{SiO}_{2}\right)$ in the whole-rock suite is supported by independent estimates of oxygen fugacity from $\mathrm{Fe}$ compositions in biotite (Stephens et al., 1985). This trend has been attributed to a gradual 
122 transition from more oxidising conditions in outer zones (close to the hematite-magnetite

123 buffer) to less oxidising conditions in the inner zones (close to the nickel-nickel oxide (NNO)

124 buffer). The assemblage quartz + magnetite + sphene also indicates conditions more

125 oxidising than the NNO buffer $+2 \log$ units of oxygen fugacity (Dilles, 1987; Wones 1989;

126 Strack and Dilles, 1998) in the outer zone of the Criffell pluton. Furthermore, a gradual

127 decrease in the modal abundance of magnetite and sphene in more silicic zones of the Criffell

128 pluton indicate that these magmas are more reduced (Xirouchakis et al., 2001). Whole-rock

129 isotope modelling suggests that the most reduced zones contain up to $\sim 30 \%$ of assimilated

130 reduced sedimentary rocks, consistent with their peraluminous compositions (Stephens et al.,

131 1985; Miles et al., 2013a).

132

133 Apatite crystals up to $1 \mathrm{~mm}$ long are found in all zones of the pluton, typically occurring as

134 inclusions in most major rock-forming minerals including zircon. Apatite REE compositions

135 have been shown to reflect bulk compositional changes in the magma and appear to have

136 crystallised over extended periods of magma evolution relative to other phases (Miles et al.,

137 2013a). Zircon occurs in all zones, although only in small amounts in Zone 5 (innermost and

138 most silicic granite). The small number of zircon crystals found in Zone 5 are often highly

139 fractured, possibly due to radiation damage. Zircon U-Pb ages (Miles et al., 2013b) reveal no

140 inherited zircon in any part of the pluton, consistent with the conclusions of an earlier study

141 (Pidgeon and Aftalion, 1978). The general absence of resorption surfaces within

142 concentrically zoned zircon crystals suggests that most are primary and do not represent 143 antecrysts. 
146 Whole-rock major oxide compositions were determined by Stephens and Halliday (1980)

147 using 'rapid wet' methods and the two-solution method of Riley (1958). $\mathrm{SiO}_{2}$ and $\mathrm{Al}_{2} \mathrm{O}_{3}$ were

148 analysed by spectrophotometric methods; $\mathrm{Na}_{2} \mathrm{O}$ and $\mathrm{K}_{2} \mathrm{O}$ by atomic emission; total $\mathrm{FeO}$,

$149 \mathrm{MnO}, \mathrm{MgO}$ and $\mathrm{CaO}$ by atomic absorption; $\mathrm{TiO}_{2}$ and $\mathrm{P}_{2} \mathrm{O}_{5}$ by colorimetry; and ferrous iron

150 by titration with potassium dichromate.

152 Apatites from the outer four zones of the Criffell pluton were analysed in thin section to provide textural context. Zircon-hosted apatite inclusions were analysed following standard

154 heavy liquid and magnetic separation of zircon and mounting in epoxy blocks. Mn

155 abundances were measured using a Cameca SX-100 electron microprobe at the University of

156 Edinburgh (concentrations converted from weight $\%$ to ppm are in Table 1). Wavelength

157 dispersive (WDS) analyses were carried out using PC0, LTAP, LPET and LIF dispersion

158 crystals. A $\sim 1 \mu \mathrm{m}, 20 \mathrm{kV}$ beam, initially at $10 \mathrm{nA}$ and defocused (to minimise the loss of 159 alkali elements during analysis) and subsequently at $60 \mathrm{nA}$ was used for analysing trace and 160 most major elements.

162 Apatite REE concentrations were determined using a Cameca ims4f ion microprobe at the

163 University of Edinburgh, with a $5 \mathrm{nA}^{16} \mathrm{O}^{-}$primary ion beam at $15 \mathrm{keV}$ net impact energy and 164 a spot size of approximately $15 \mu \mathrm{m}$. Only high energy secondary ions (100-140 eV) were 165 measured in order to reduce molecular ion overlap. $\mathrm{F}^{-} / \mathrm{Ca}^{2+}$ ion yields were determined using 166 Durango and Wilberforce standards. Corrections were made for CeF at mass 159 based on 167 the observed $\mathrm{F}$ content and previous measurements of 159 variability with energy measured on Durango apatite. The LREE ion yields were calculated relative to glass standard SRM610

169 (Pearce et al., 1997) and multiple apatite standards (Steven Burgman, pers. comm.), but 170 because of limited element coverage, the HREE were based on measurements of Durango 
apatite alone. Uncertainties in absolute concentrations should be better than $20 \%$ but relative concentrations are $<5 \%$ where not limited by counting statistics. Analysis spots were subsequently examined for cracks and inclusions using back-scattered electron (BSE) and cathodoluminescence (CL) images of polished surfaces obtained with a Philips XL30P Scanning Electron Microscope (SEM) at the University of Edinburgh.

Approximately 100 zircon crystals per sample were separated, with 10 crystals per sample analysed by ion microprobe at the University of Edinburgh using a Cameca ims-4f ion microprobe. Zircon trace elements were analysed at $15 \mathrm{keV}$ net impact energy using a 15

$180 \mu \mathrm{m}$ diameter primary ${ }^{16} \mathrm{O}^{-}$beam at $\sim 5 \mathrm{nA}$ with $4.5 \mathrm{keV}$ secondary positive ions measured at $181120 \mathrm{keV}$ offset following the method of Hinton and Upton (1991). Measurements were made at low mass resolution applying a large energy offset $(100-140 \mathrm{eV})$ to minimise molecular ion overlaps. Corrections were made for $\mathrm{ZrSiO}^{+}$based on the mass 134 count rates and were typically equivalent to $0.015 \mathrm{ppm} \mathrm{La}$ and $0.002 \mathrm{ppm}$ Pr. Analysis times were set longer for 185 species at lower concentrations or for low abundance isotopes giving relatively constant 186 errors across the LREE (with the exception of Ce). For a typical zircon pattern increasing in concentration from $0.05 \mathrm{ppm} \mathrm{La}$ to $0.2 \mathrm{ppm} \mathrm{Eu}$, the counting errors of a single analysis for all the LREE is approximately $30 \%$ ( $1 \mathrm{SD}$ ). This error falls to $8 \%$ if the concentrations are 10 times higher (i.e. values typical for the measurements made here). For Ti (used for 190 thermometry), $1 \mathrm{SD}$ errors are typically $5 \%$ at $8 \mathrm{ppm}$, rising to $10 \%$ at $2.5 \mathrm{ppm}$ and about $7 \%$ 191 in the normal 4-5 ppm range. The detector background was measured at mass 130.5 and was $<0.01 \mathrm{cps}$ (equivalent to $\approx 0.005 \mathrm{ppm} \mathrm{La)} \mathrm{based} \mathrm{on} \mathrm{a} \mathrm{combined} \mathrm{measurement} \mathrm{over} 2$ days and no corrections were made for detector background. Corrections were made for the overlap of LREE oxides on HREE. Because of the low LREE abundances, corrections for LREE oxides on the HREE were rarely more than $3 \%$ and any error related to the correction likely to be 
significantly less than $1 \%$. Concentrations were determined relative to NIST610 glass (Pearce et al., 1997) in the similar manner to that described in Weidenbeck et al. (2004) and Hinton and Upton (1991) and secondary zircon standard 91500 was used (Weidenbeck et al. (2004).

\section{Results}

\subsection{Mn, Fe and Eu contents in apatites and whole-rocks}

All zones of the Criffell pluton contain predominantly fluor-apatite $\left(\mathrm{Ca}_{5}\left(\mathrm{PO}_{4}\right)_{3}\right) \mathrm{F}$. Total $\mathrm{Mn}$ concentrations in apatite increase systematically by up to a factor of $\sim 27$ between Zone 1 (190 - 582 ppm) and Zone 4 (1713 - 5076 ppm) (Fig. 3a; Table 1). Yet Mn in the whole-rock shows a subtle decrease with increasing $\mathrm{SiO}_{2}$ (Fig. 3a; Supplementary Material 1), demonstrating that $\mathrm{Mn}$ is more easily partitioned into apatite in the more silicic zones. Electron probe traverses carried out across individual crystals in zones 1 and 2 reveal no significant compositional zonation, with almost all Mn analyses within analytical error $(\sim 150 \mathrm{ppm})$ of each other (Supplementary Material 2). There is no evidence to suggest that the Mn concentrations of apatite inclusions are dependent on the host mineral (Table 1). Total Fe concentrations in apatites are mainly between $\sim 100$ and $4600 \mathrm{ppm}$ and when not distinguished according to their host phase, appear not to vary systematically between zones and display similar degrees of variability within and between zones (Fig. 3b). However, unlike $\mathrm{Mn}, \mathrm{Fe}$ concentrations in all zones show marked increases in apatites hosted by $\mathrm{Fe}$ rich minerals such as hornblende and biotite. This is likely to reflect secondary fluorescence of $\mathrm{Fe}$ caused by the proximity of analytical spots in apatite inclusions to Fe-rich host minerals. Using a beam voltage of $20 \mathrm{kV}$, penetration depths are likely to be $\sim 9 \mu \mathrm{m}$ (calculated using Electron Flight Simulator version 3.01). However, the range of 
characteristic X-rays and Bremsstrahlung that are generated by incident electrons is typically one or two-orders-of-magnitude greater (up to several tens or hundreds of microns, Llovet and Galan, 2003). Fe concentrations in apatites hosted by Fe-poor minerals such as zircon, quartz and feldspar display the same trend shown by Mn, increasing from between $\sim 100$ and 300 ppm in zones 1 and 2,140 and 840 ppm in Zone 3 and 260 and 1700 ppm in Zone 4 (Fig. 3b). Whole-rock $\mathrm{Fe}_{2} \mathrm{O}_{3}\left(\mathrm{Fe}^{3+}\right)$ varies from $\sim 2.1 \times 10^{3} \mathrm{ppm}$ to $1.8 \times 10^{4} \mathrm{ppm}$ and shows a general decrease with increasing $\mathrm{SiO}_{2}$ (Fig. 3b). $\mathrm{Mn} / \mathrm{Fe}$ ratios in apatites (excluding those hosted in hornblende and biotite) show an increase in their maximum values from Zone $1($ all $<3)$ to Zone 4 (all < 12) (Fig. 3c). For whole-rock, $\mathrm{MnO} / \mathrm{FeO}_{\text {Total }}$ (where 'Total' refers to $\mathrm{Fe}_{2} \mathrm{O}_{3}+$ $\mathrm{FeO}$ ) increases from 0.017 to 0.035 with increasing $\mathrm{SiO}_{2}$ (Fig. 3c).

Chondrite-normalised REE profiles for the Criffell apatites show a marked increase in the magnitude of their negative $\mathrm{Eu}$ anomalies $\left(\mathrm{Eu} / \mathrm{Eu}^{*}\right.$ ) from zones 1 to 4 (Miles et al., 2013a) and are presented here in Figure 4. Apatites in Zone 1 generally have $\mathrm{Eu} / \mathrm{Eu}^{*}$ values of between 0.7 and 1, while those from zones 4 and 5 have $\mathrm{Eu} / \mathrm{Eu}^{*}$ values that are all $<0.4$ (Fig. 4). Whole-rock compositions from the Criffell pluton are noteworthy for their very small Eu anomalies, particularly in the granodiorite zones (Stephens et al., 1985), suggesting that apatites cannot have inherited their Eu anomaly characteristics from the bulk-rock magmas.

\subsection{Ce in zircon and crystallisation temperatures}

240 Positive Ce anomalies (calculated using the expression Ce/Ce* $=\mathrm{Ce}_{\mathrm{N}} /\left(\mathrm{La}_{\mathrm{N}} \times \operatorname{Pr}_{\mathrm{N}}\right)^{1 / 2}$, where element abundances are normalised $(\mathrm{N})$ to chondrite, are a common feature of igneous zircon

242 (Fig. 5; Table 2), reflecting the ability of Ce to exist as $\mathrm{Ce}^{4+}$ under oxidising conditions 243 (Hinton and Upton, 1991; Ballard et al., 2002; Hoskin and Schaltegger, 2003; Trail et al., 
244 2011; 2012; Burnham and Berry, 2012). At magmatic temperatures, homogenisation of REE

245 concentrations at a $10 \mu \mathrm{m}$ scale in zircon only occurs on timescales greater than the age of the

246 Earth (Cherniak and Watson, 2003). Unlike Eu anomalies, Ce anomalies are not influenced

247 by feldspar crystallisation. Large Ce anomalies in zircon are thought to reflect a $\sim 4$ to 6

248 orders of magnitude increase in the compatibility of $\mathrm{Ce}^{4+}$ relative to $\mathrm{Ce}^{3+}$ (the latter represents

$24999.0 \%$ to $99.7 \%$ of the total Ce in most melts) rather than large increases in the abundance of

$250 \mathrm{Ce}^{4+}$ (Ballard et al., 2002; Colombini et al., 2011). The increased solubility of $\mathrm{Ce}^{4+}$ is likely to

251 result from similarities in its size and charge relative to $\mathrm{Zr}^{4+}$ for which it substitutes. Median

$252 \mathrm{Ce} / \mathrm{Ce}^{*}$ values for zircon in zones 1 to 3 of the Criffell pluton are similar and range from 52

253 to 63 (Fig. 5b), while the median value for Zone 4 is much lower at 28. Every zone is

254 characterised by significant scatter in $\mathrm{Ce} / \mathrm{Ce}^{*}$ values, the three outermost zones having interquartile values (within which $50 \%$ of the data reside) of $\sim 18$ to 34 while the innermost analysed zone (Zone 4) has an interquartile value of $\sim 107$.

Zircon crystallisation temperatures have been calculated (Table 2) using the modified Ti-inzircon thermometer of Ferry and Watson (2007), allowing for variations in the activity of Si and $\mathrm{Ti}$. The inherent problems of assessing these activities at the time of zircon crystallisation mean that the thermometer provides only semi-quantitative estimates of crystallisation temperatures. However, overestimates or underestimates of silica and titanium activities result in offsetting errors in crystallisation temperatures (Ferry and Watson, 2007). The abundance of quartz in all zones makes it likely that silica activity was at or close to unity during zircon saturation, so estimated crystallisation temperatures will be towards the top of the range. A lack of rutile in analysed samples indicates that titanium activity was below unity; however, the presence of other Ti-rich phases such as sphene in the outer zones of the pluton indicates that Ti activity was not very low (an observation made in other plutons, e.g. 
269 Hayden and Watson, 2007; Claiborne et al., 2010). We therefore assume a titanium activity 270 value of 0.7 after Claiborne et al., (2010). Average zircon crystallisation temperatures and 271 standard deviations are effectively indistinguishable at $680( \pm 32){ }^{\circ} \mathrm{C}, 669( \pm 24){ }^{\circ} \mathrm{C}, 681( \pm$ $27238)^{\circ} \mathrm{C}$ and $634( \pm 32)^{\circ} \mathrm{C}$ in zones 1 to 4 respectively (Table 2$)$.

\section{Discussion}

Mn concentrations increase significantly in apatite relative to whole-rock during magma evolution in a number of granitic plutons $\left(\mathrm{SiO}_{2}>63 \mathrm{wt} \%\right)$ that exhibit evidence for assimilation of sedimentary rocks (Fig. 6) (Sha and Chappell, 1999; Belousova et al., 2001; 2002; Chu et al., 2009; Cao et al., 2011; Mazhari and Attar, 2012). The assimilation of reduced sedimentary material in particular has commonly been shown to result in the

281 formation of more reduced and peraluminous silicic granitic magmas (see Takagi, 2004 and references therein). By contrast, apatite in $\mathrm{SiO}_{2}$-rich metaluminous plutons that attain more silicic compositions by fractional crystallisation alone often show only limited variations in Mn concentration relative to their whole-rocks (see data from Chu et al., 2009, Fig. 6). Redox conditions in these latter plutons are therefore unlikely to have changed significantly during magma evolution. The apparent increase in Mn partitioning in apatite observed under more reducing conditions in a number of plutons therefore appears to be largely independent of the Mn composition of the original melts and may instead depend on other factors such as redox conditions.

291 Several studies have developed the use of apatite as a provenance indicator based on the different concentrations of $\mathrm{Mn}$ and other elements in apatites from different granite sources 
293 (e.g. Sha and Chappell, 1999; Hoskin et al., 2000; Belousova et al., 2001; 2002; Chu et al., 294 2009). Although links have been drawn between the abundance of $\mathrm{Mn}$ in apatites and the 295 redox states of different granitic magmas (e.g. Sha and Chappell, 1999; Belousova et al., 296 2001; Chu et al., 2009), no attempt has been made to evaluate $f \mathrm{O}_{2}$ values using apatite $\mathrm{Mn}$ 297 concentrations and the extent to which redox proxies in magmatic apatite and zircon are 298 complementary to each other and to other redox proxies.

\subsection{Redox and other controls on apatite compositions}

Apatite, a common constituent of intermediate to silicic igneous rocks, has the general formula $\mathrm{Ca}_{10}\left(\mathrm{PO}_{4}\right)_{6}(\mathrm{OH}, \mathrm{F}, \mathrm{Cl}, \mathrm{Br})_{2}$ and a crystal structure consisting of rigid $\mathrm{PO}_{4}$ tetrahedra, a 9-fold $\mathrm{Ca} 1$ site and a $\mathrm{Ca} 2$ site bonded to six oxygen atoms and one anion $(\mathrm{Cl}, \mathrm{F}, \mathrm{OH})$. The apatite structure is highly tolerant of structural distortion and chemical substitutions, and can therefore display a wide variety of compositions (Pan and Fleet, 2002), which includes the incorporation of redox-sensitive elements like $\mathrm{Mn}, \mathrm{Fe}$ and the REEs. The maximum $\mathrm{Mn}$ content in natural fluorapatite is $1.37 \mathrm{Mn}$ per formula unit, with $\mathrm{Mn}^{2+}$ substituting preferentially onto Ca1 sites (Pan and Fleet, 2002).

In the Criffell pluton the Mn content of apatite increases as ferric iron $\left(\mathrm{Fe}^{3+}\right)$ decreases in the

311 whole-rock (Fig. 3); the concentration of ferric iron is strongly controlled by the redox state 312 of the magma (Lee et al., 2010 and references therein). More oxidised outer zones (zones 1 313 and 2) of the pluton formed from magmas with elevated $\mathrm{Fe}^{3+} / \mathrm{Fe}^{2+}$ (Stephens et al., 1985) 314 which are also likely to have had elevated $\mathrm{Mn}^{3+} / \mathrm{Mn}^{2+}$. By contrast, the innermost granites 315 (zones 4 and 5) are characterised by lower whole-rock $\mathrm{Fe}^{3+}$ and more reducing conditions.

$316 \mathrm{Mn}^{2+}$ exhibits similarities in ionic radius when in 7- $(0.9 \AA)$ and 9-fold $(1.0 \AA)$ coordination

317 with $\mathrm{Ca}^{2+}(1.14 \AA)$, with which substitution occurs. By comparison, $\mathrm{Mn}^{3+}$ has an ionic radius 
318 of $0.62 \AA$ to $0.67 \AA$ depending on the degree of distortion, and requires the existence of cation

319 vacancies or the possible substitution of additional charge-balancing ions in the crystal

320 lattice. One possibility may include a coupled substitution such as $\mathrm{Mn}^{3+}+\mathrm{Si}^{4+}=\mathrm{Ca}^{2+}+\mathrm{P}^{5+}$

321 as suggested for the substitution of some $\mathrm{REE}^{3+}$ in apatite (Sha and Chappell, 1999) and may

322 in part account for the elevated Si contents of apatites in more oxidised zones (Table 1). To a

323 large extent, the increased compatibility of $\mathrm{Mn}$ in apatites from reduced zones of the pluton is 324 likely to result from the increased compatibility of $\mathrm{Mn}^{2+}$ relative to $\mathrm{Mn}^{3+}$ in these zones.

325 Some spectroscopic data also indicates that $\mathrm{Mn}^{5+}$ may substitute for $\mathrm{P}^{5+}$, although the former 326 is likely to represents no more than 5\% of total Mn in apatite (Hughes et al., 2004).

\subsubsection{Preservation of Mn compositions in apatite}

Do variations in $\mathrm{Mn}$ in apatite reflect magmatic conditions at the time of crystallisation or later modifications? Assuming an effective diffusion radius of $250 \mu \mathrm{m}$ and temperatures of $\sim 700^{\circ} \mathrm{C}$ (estimated by Ti-in-zircon thermometry; see Table 2), apatite crystal cores are expected to retain close to initial Mn concentrations on timescales of $\sim 10^{6}$ years (Cherniak, 2005). However, silicic plutonic rocks are unlikely to be held at such temperatures for extended periods of time and particularly not when they are assembled incrementally by the emplacement of small melt batches, as is thought to have occurred during development of the

337 Criffell pluton (Miles et al., 2013a). Once cooled to below $600^{\circ} \mathrm{C}$, retention times for initial

338 Mn concentration in crystal cores increases to $\sim 10^{8}$ years or more (Cherniak, 2005).

339 Furthermore, a number of the apatite crystals analysed as part of this study have dimensions

340 that are significantly larger than the effective diffusion radius used above. Although some

341 fine-scale intracrystal compositional zoning may be lost, it is reasonable to assume that apatite largely retains $\mathrm{Mn}$ concentrations from the time of crystallisation providing subsequent prolonged and extreme thermal events can be ruled out. It is possible that the 
absence of significant $\mathrm{Mn}$ zoning in apatites from zones 1 and 2 may have resulted from small-scale homogenisation.

\subsubsection{Other potential controls on Mn partitioning in apatite}

It is also important to explore other potential controls on Mn uptake in apatite that are independent of, or additional to, the effects of redox conditions. Assuming that $\mathrm{Mn}^{3+}$ is incompatible in apatite $\left(D_{M n 3+}^{A p-m e l t}=0\right)$, the observed decrease in $D_{M n}^{A p-m e l t}$ (about 90\%) between reduced and oxidised zones may suggest that under the most oxidised conditions, the proportion of $\mathrm{Mn}$ that occurs as $\mathrm{Mn}^{3+}$ also increases by a similar amount. This seems unlikely based on limited knowledge of redox relations in silicate melts, which suggest that $\mathrm{Mn}^{3+}$ represents only a few percent of all Mn (e.g. Schreiber, 1987). Assuming that $\mathrm{Mn}^{3+}$ is only moderately incompatible in apatite, but less compatible than $\mathrm{Mn}^{2+}$, may require additional $\mathrm{Mn}$ to be present as $\mathrm{Mn}^{3+}$. Thus it is possible that other factors such as temperature, composition and competition with other Mn-bearing minerals may act in addition to redox controls, permitting additional $\mathrm{Mn}^{3+}$ to enter the apatite structure at granitic temperatures.

360 Further experimental calibration is needed to fully address these potential issues, but here we examine some of the empirical evidence for other possible controls on the uptake of $\mathrm{Mn}$ in apatite.

Temperature controls on Mn partitioning

365 Published partition coefficient data for $\mathrm{Mn}$ in apatite are rare and it remains difficult to fully assess the effects of temperature on Mn partitioning. Apatite is known to crystallise over a range of temperatures in felsic metaluminous magmas because it saturates early relative to other minerals (Piccoli and Candela, 1994; Streck and Dilles, 1998; Miles et al., 2013a). Apatite saturation temperatures (calculated using measured concentrations of $\mathrm{SiO}_{2}$ and $\mathrm{P}_{2} \mathrm{O}_{5}$ 
in the whole-rock, Harrison and Watson, 1984; Piccoli and Candela, 1994) vary between

$371912^{\circ} \mathrm{C}$ and $988^{\circ} \mathrm{C}$ across all zones of the Criffell pluton, show little variation between zones

372 (Supplementary Material 1) and support the idea of early apatite crystallisation that is

373 consistent with textural evidence showing that most apatite crystals exist as inclusions within

374 other minerals (Miles et al., 2013a). It is suggested that $>50 \%$ of apatite crystallises within

$37560^{\circ} \mathrm{C}$ of its liquidus temperature and $90 \%$ within $140^{\circ} \mathrm{C}$ (Piccoli and Candela, 1994; Streck

376 and Dilles, 1998). Individual apatite crystals may therefore represent only part of an extended

377 crystallisation history (Miles et al., 2013a) and further experimental work is required to fully

378 assess the importance of temperature in controlling Mn partitioning in apatite. However, the

379 limited variations in apatite saturation temperatures and textural occurrence of apatites

380 between zones in the Criffell pluton would indicate that other factors, including redox conditions may still exert a strong control on the partitioning of $\mathrm{Mn}$ in apatite.

382

\section{Mineralogical and compositional controls on Mn partitioning in apatite}

384 The presence of other Mn-bearing minerals, such as biotite, amphibole and magnetite, also

385 influence Mn concentrations in apatite insofar as they affect the evolution of melt compositions. It is therefore reasonable to speculate about whether increased concentrations of $\mathrm{Mn}$ in apparently more reduced zones reflect the absence of amphibole and the lower abundance of biotite and magnetite in these zones. Published whole-rock data (Stephens et al., 1985) have been used to estimate initial $\mathrm{MnO}$ concentrations of $0.06 \mathrm{wt} \%$ and $0.05 \mathrm{wt} \%$

390 in oxidised (Zone 1) and reduced (Zone 5) zones respectively. The observed modal proportions (volume proportions) of Mn-bearing minerals (oxidised zones: 1\% magnetite, $10 \%$ biotite, $5 \%$ amphibole; reduced zones: $5 \%$ biotite) together with published mineral-melt partition coefficients (Latourrette et al., 1991; Ewart and Griffin, 1994; Dawson and Hinton,

394 2003) have been used to calculate the concentrations of Mn available for apatite in the 
remaining melt volume after fractional crystallisation of other Mn-bearing minerals that crystallise according to their modal proportions. The maximum 27 fold increase in $\mathrm{Mn}$ concentrations observed between apatites in zones 1 and 4 requires $>90 \%$ crystallisation of both zones prior to the onset of apatite crystallisation (Supplementary Material 4). Late crystallisation of apatite is at odds with textural evidence for the inclusion of apatite in other host minerals and apatite saturation temperatures of $>900^{\circ} \mathrm{C}$, both of which indicate that apatite crystallised earlier than most other minerals. After more modest levels of fractional crystallisation $(\sim 50 \%)$, Mn concentrations only increase by a factor of $\sim 2$ from zones 1 to 4 (Supplementary Material 4). It therefore seems unlikely that the crystallisation of other Mnbearing minerals will have significantly influenced the uptake of Mn in apatites in the Criffell pluton. A further possibility is that the partitioning of Mn in apatite, or more specifically the activity coefficient of $\mathrm{Mn}(\gamma \mathrm{Mn})$, is compositionally dependent. Wood and Wade (2013) have recently shown that in silicate melts, the activity coefficient for $\mathrm{Fe}(\gamma \mathrm{Fe})$ is only very weakly compositionally dependent over a wide range of silicate melt compositions, but further experimental calibration is required to fully examine the influence of melt chemistry and aluminosity on Mn partitioning in apatite.

Fe can constitute up to $\sim 1 \mathrm{wt} \%$ in apatite, and Mössbauer spectroscopy suggests that $\mathrm{Fe}^{2+}$ is readily substituted onto both Ca sites (Pan and Fleet, 2002). Despite a lack of published

416 evidence for $\mathrm{Fe}^{3+}$ incorporation in apatite, it would appear to be plausible using similar 417 crystal chemistry arguments to those discussed previously for $\mathrm{Mn}^{3+}$. Fe concentrations in apatite are expected to mirror that of $\mathrm{Mn}$, with an increased abundance of $\mathrm{Fe}$ in apatite under

419 reduced conditions caused by higher concentrations of more compatible $\mathrm{Fe}^{2+}$ in the melt 420 relative to $\mathrm{Fe}^{3+}$. The elevated $\mathrm{Fe}$ concentrations measured by electron microprobe in apatites 
hosted by Fe-rich minerals is attributed to the effect of secondary fluorescence. Fe analyses of apatites hosted by Fe-poor minerals like quartz and feldspar appear to follow the expected trend, with increased concentrations of Fe in apatites from more reduced zones (Fig. 3b).

$\mathrm{Mn} / \mathrm{Fe}$ ratios are known not to vary in response to fractional crystallisation in primitive magmas and may thus reveal changes in redox state providing the $\mathrm{Mn} / \mathrm{Fe}$ ratios of source components are known (Canil et al., 1994; Ruzika et al., 2001). However, in this study and others (Miller and Stoddard, 1981; Cerny et al., 1985; London et al., 2001), granitic suites of rocks show increases in $\mathrm{MnO} / \mathrm{FeO}_{\text {Total }}$ ratios with indices of differentiation like $\mathrm{SiO}_{2}$. 430 However, this effect is likely to result from the ability of biotite and magnetite to preferentially fractionate $\mathrm{Fe}\left(\mathrm{Kd}_{\mathrm{Bt} / \text { melt }} \approx 25 ; \mathrm{Kd} \mathrm{Mt}_{\mathrm{melt}} \approx 150\right)$ from $\mathrm{Mn}\left(\mathrm{Kd}_{\mathrm{Bt} / \mathrm{melt}} \approx 5 ; \mathrm{Kd} \mathrm{Mt}_{\mathrm{melt}} \approx\right.$ 15) in silicic magmas. For example, assuming a starting composition similar to that of the most primitive Criffell magma and modal (volume) proportions of magnetite $(0.1 \%)$ and biotite (10\%), Mn/Fe ratios increase by a factor of approximately 10 after $50 \%$ fractional crystallisation (Supplementary Material 4). It is therefore difficult to assess the degree to which increases in $\mathrm{Mn} / \mathrm{Fe}$ seen in apatites from more silicic zones result from redox and/or crystallisation effects.

439 The ability of Eu to exist in two valency states $\left(\mathrm{Eu}^{2+}\right.$ and $\left.\mathrm{Eu}^{3+}\right)$ may also provide a means of 440 independently estimating the redox state of host magmas. The difference in ionic radius 441 between $\mathrm{Eu}^{3+}$ and the $\mathrm{Ca}^{2+}$ ions with which it substitutes in apatite is smaller than that 442 between $\mathrm{Eu}^{2+}$ and $\mathrm{Ca}^{2+}$ in both seven and nine-fold coordination (Cao et al., 2011). 443 Consequently, apatite shows a marked preference for $\mathrm{Eu}^{3+}$ relative to $\mathrm{Eu}^{2+}$ (e.g. Prowatke and 444 Klemme, 2006). Increasingly negative Eu anomalies in apatites from more silicic zones in the 445 Criffell pluton (Fig. 4) might therefore indicate an increase in $\mathrm{Eu}^{2+} / \mathrm{Eu}^{3+}$ in those magmas due 
446 to more reducing conditions. Additionally, the absence of significant Eu anomalies in whole447 rock samples from all zones (Stephens et al., 1985) shows that the observed anomalies in 448 apatite were not inherited from their host magmas, although they could reflect more localised 449 effects during crystallisation, particularly if apatite crystallisation occurred later than most 450 feldspar. The absence of Eu anomalies in whole-rock from granodiorite zones is thought to 451 reflect oxidising conditions, close to the magnetite-hematite buffer (Stephens et al., 1985) or at least more oxidising than NNO+1.5 (Dilles 1987), that did not favour $\mathrm{Eu}^{2+}$ partitioning into plagioclase. More reducing redox conditions (close to the NNO buffer) in more silicic zones should have favoured the formation of negative $\mathrm{Eu}$ anomalies in the whole-rock due to the uptake of $\mathrm{Eu}^{2+}$ by plagioclase (Stephens et al., 1985). Despite this, whole-rock compositions in granitic zones do not exhibit any significant Eu anomalies (Stephenson et al., 1985).

Whole-rock compositions in the Criffell pluton are thought to have been determined at depth, within a crustal hot zone through fractional crystallisation and assimilation of reduced 460 sedimentary rocks (Miles et al., 2013a; Annen et al., 2006). In this model, low viscosity, $461 \mathrm{H}_{2} \mathrm{O}$-rich magmas segregate and ascend adiabatically in a super-liquidus state. The absence 462 of $\mathrm{Eu}$ anomalies in the granitic zones may therefore reflect resorption of plagioclase during ascent of incremental magma batches prior to final crystallisation at shallower levels (Miles et al., 2013a). Alternatively, redox conditions may only have become significantly more 465 reducing after melt segregation from the crustal hot zone. One possible means of changing 466 oxidation states during differentiation is through the reaction of water with ferrous $\mathrm{Fe}$ 467 (Holloway et al., 2004; Lee et al., 2010). This reaction is thought to result in the formation of 468 micro-crystalline magnetite and degassing of $\mathrm{H}_{2}$, causing possible auto-oxidation. The redox conditions of ascending magmas have also been shown to vary in relation to the amount of 
470 gas in the magma reservoir, with sulphur-rich magmas exhibiting either increases or 471 decreases in redox states that depend on their initial $f \mathrm{O}_{2}$ (Burgisser and Scaillet, 2007).

472

473 Irrespective of why oxidation states vary during differentiation, it is unlikely that feldspar 474 which crystallised at shallow levels either accumulated or was lost from viscous granitic 475 magmas. Despite this, large Eu anomalies may still be induced in coexisting minerals under 476 suitably reducing conditions in the interstitial melt. This effect may explain why co-existing apatite crystals in the most reduced zones (zones 3 and 4) exhibit large negative Eu anomalies (Fig. 4) relative to those in more oxidised zones (zones 1 and 2) of the pluton while wholerock compositions exhibit little or no negative Eu anomalies. Apatite that crystallises later and at lower temperatures may also exhibit larger negative anomalies due to earlier feldspar crystallisation, though apatite saturation temperatures do not vary appreciably between zones and most apatite in all zones is likely to have crystallised prior to most other minerals.

Unlike zircon, Ce anomalies are not developed in apatites from any zone of the Criffell pluton. This probably reflects the greater compatibility of $\mathrm{Ce}^{3+}\left(\mathrm{Ce}^{3+}\right.$ and $\mathrm{Ca}^{2+}$ have very similar ionic radii and identical charges) and the extremely low concentration of relatively incompatible $\mathrm{Ce}^{4+}$ (Colombini et al., 2011). Unlike zircon, Ce is present almost exclusively as $\mathrm{Ce}^{3+}$ in apatite irrespective of redox conditions.

\subsection{Redox states determined from $\mathrm{Ce} / \mathrm{Ce}^{*}$ in zircon}

Unlike apatite, the positive Ce anomaly commonly seen in igneous zircon has long been considered to reflect redox conditions in the magma at the time of crystallisation (Hinton and Upton, 1991; Ballard et al., 2002; Trail et al., 2011; 2012; Burnham and Berry, 2012). In a

494 recent experimental study, Trail et al., (2011) calibrated the magnitude of the Ce anomaly 
against $f \mathrm{O}_{2}$ at $900-1300^{\circ} \mathrm{C}$, and applied their method to natural Hadean zircons from Jack Hills (Western Australia) in order to examine the oxidation state of the original host magmas.

The $\mathrm{Ce} / \mathrm{Ce} *$ values of zircons, and their crystallisation temperatures, from zones 1 to 4 of the Criffell pluton have been used to calculate $\mathrm{fO}_{2}$ using the experimentally calibrated expression of Trail et al., (2011). The values are reported relative to the fayalite-magnetite-quartz (FMQ) buffer (at standard pressure conditions of 1 bar) for each calculated crystallisation temperature in log units ( $\triangle \mathrm{FMQ})$ (Fig. 7, Table 2). Each unit represents one log unit deviation in $f \mathrm{O}_{2}$ from the FMQ buffer, where positive values signify more oxidised conditions and negative values more reduced conditions than those of the buffer. Median $\triangle F M Q$ values decrease steadily from +2.5 to +2 to -0.8 to $-2 \log$ unit deviations from the FMQ buffer in zones 1 to 4 respectively (Fig. 7). However, there is also significant intra-sample scatter, with

507 interquartile ranges up to $~ 10 \log$ units in Zone 4, similar to those reported by Trail et al., 508 (2011) for the Bishop Tuff.

It is questionable whether large variations in $\mathrm{Ce} / \mathrm{Ce} *$ (and therefore $f \mathrm{O}_{2}$ ) calculated for natural 511 samples in both studies reflect real variations in redox conditions. Variations in $\mathrm{Ce} / \mathrm{Ce}$ * may 512 result either from changes in the partitioning of $\mathrm{Ce}$ into zircon, that in turn reflect redox 513 conditions, or from changes in the relative concentrations of La and Pr. The latter effect is 514 particularly problematic in zircon due to the naturally low concentrations of $\mathrm{La}$ and $\operatorname{Pr}$, 515 making LREE analyses especially susceptible to beam overlap with small LREE-rich 516 inclusions (Nagasawa, 1970; Colombini et al., 2011; Trail et al., 2012). One way of testing 517 these interpretations is to use independent proxies for both effects. Sm in zircon is insensitive 518 to redox effects and is found at sufficiently high concentrations in zircon that inclusions of 519 LREE-rich minerals would have only a negligible effect. In an attempt to avoid the effects of 
520 LRRE-rich inclusions in zircon, Ballard et al. (2002) suggest that La and Pr concentrations in apatite may be estimated by extrapolation of zircon HREE chondrite-normalised patterns. However, some suggest that the partitioning of LREE into zircon may be limited by different factors to those that control the partitioning of HREE (Finch et al., 2001; Hanchar et al., 2001). There is no suggestion that the partitioning of Sm into zircon is limited by different factors to those that control the partitioning of LREE. La/Sm ratios in zircon therefore provide a proxy for the presence of LREE-rich inclusions like allanite and monazite, while $\mathrm{Ce} / \mathrm{Sm}$ ratios reflect changes in the partitioning of $\mathrm{Ce}$ into zircon caused by redox changes; the use of ratios in both cases negates the effects of varying magma compositions. For natural samples from this study and the Bishop Tuff (Reid et al., 2011), there is a clear tendency for

$530 \mathrm{Ce} / \mathrm{Ce}^{*}$ to reflect variations in the concentrations of LREE other than Ce (Fig. 8). By contrast, there is no such tendency for $\mathrm{Ce} / \mathrm{Ce} *$ to correlate with $\mathrm{La}$ and $\mathrm{Pr}$ in synthetic zircons used by Trail et al., (2011) to experimentally calibrate their oxybarometer, which instead reflects real variations in the partitioning of Ce into zircon under different redox conditions.

Measured concentrations of LREE in natural zircons vary significantly (Hanchar and van Westrenen, 2007), and it is estimated that inclusion concentrations as low as 0.01 to 0.001 volume \% may have a significant effect on the measured LREE content of zircon (Jain et al., 2001). Small amounts of allanite and/or monazite found in heavy mineral separates prepared from samples from all zones of the Criffell pluton support the possibility that small inclusions

540 may be present in zircons, and may in part account for the larger scatter in $f \mathrm{O}_{2}$ values

541 calculated from Ce/Ce*. In addition, ion microprobe analyses of LREE concentrations in zircons are close to background levels (see Methods) and may result in further errors when

543 calculating $\mathrm{Ce} / \mathrm{Ce}^{*}$ values. Although the experimental calibration of Trail et al., (2011)

544 provides an important new approach to oxybarometry, conventional methods of calculating 
$545 \mathrm{Ce} / \mathrm{Ce}^{*}$ in natural zircons remain subject to large uncertainties such as those evident in Figure

546 7. The method adopted in Figure 8 may provide a general approach to assessing and

547 interpreting REE analyses of natural zircons by micro-analytical techniques and recognising

548 the possible impact of small mineral inclusions on analyses.

To investigate the potential of using Mn concentrations in apatites as a magma oxybarometer and redox proxy, we have used a range of examples where apatite compositions are available together with independent estimates of redox conditions. The average concentration of $\mathrm{Mn}$ in apatites from eight intermediate and silicic volcanic eruptions are summarised by Peng et al. (1997) whilst Scaillet et al., (1998) documented redox conditions for a number of these eruptions. For the Criffell pluton, $\mathrm{Fe}^{3+} / \mathrm{Fe}^{2+}$ in biotites from granodiorite and granite samples indicate $f \mathrm{O}_{2}$ values that are close to the magnetite-hematite and NNO buffers respectively (Stephens et al., 1985). Apatite Mn concentrations in all samples fall along a consistent trend, where Mn concentrations show a strong negative linear correlation with $\log f \mathrm{O}_{2}\left(\mathrm{R}^{2}=0.9\right.$, Fig. 9) according to the following relationship:

$$
\log f \mathrm{O}_{2}=-0.0022( \pm 0.0003) \mathrm{Mn}(\mathrm{ppm})-9.75( \pm 0.46)
$$

564 This preliminary empirical calibration is likely to apply to systems that lie within the range of eruption temperatures $\left(660-920^{\circ} \mathrm{C}\right.$, Supplementary Material 5) and compositions (andesite to rhyolite) shown by these data. Direct experimental calibration of this oxybarometer is now required in order to provide a more robust proxy than zircon for determining redox conditions

568 in intermediate and silicic magmas and to properly examine the controls on Mn partitioning in apatite. Despite the remaining uncertainties in understanding the relative importance of 
redox and other potential controls on Mn partitioning in apatite, empirical evidence from

571

572

573

574

575

576

577

578

579

580

581

582

583

584

585

586

587

588

589

590

591

592

593

594

595 natural samples indicate that it is a useful proxy for assessing the degree of oxidation across a wide range of intermediate to silicic magmas.

\section{Wider applications of an apatite oxybarometer}

Apatite may be of particular value in reconstructing the redox conditions of intermediate and silicic eruptions where redox conditions are known to strongly influence emissions of climatically important elements such as sulphur (Scaillet et al., 1998; Robock, 2000). In the presence of only $1-5 \mathrm{wt} \%$ fluid, there is a marked preference for sulphur to partition into the fluid rather than the melt under oxidising conditions $\left(f \mathrm{O}_{2}>\mathrm{NNO}+1\right.$, Scaillet et al., 1998). Excess sulphur generated in this way may account for the discrepancy between the amount of sulphur actually measured in emissions and the amount of sulphur in emissions that is expected from melt degassing calculations, and may also ensure that oxidised, explosive silicic eruptions like Fish Canyon (21.8 Ma, $f \mathrm{O}_{2} \sim \mathrm{NNO}+2$, Johnson and Rutherford, 1989) are of significant climatic importance. Many eruptions where calculated $\mathrm{fO}_{2}$ values suggest oxidising conditions, such as the 1991 Pinatubo eruption, also contain apatites that are only marginally more enriched in Mn than their host magmas (Peng et al., 1997; Van Hoose et al., 2013) and provide further credence that $\mathrm{Mn}$ in apatite may be a reliable proxy for redox conditions. By contrast, similarly voluminous but more reduced eruptions such as at Toba $\left(74,000 \mathrm{yrs}, f \mathrm{O}_{2}<\mathrm{NNO}+1\right.$, Chesner, 1998; Scaillet et al., 1998) are thought to have had a more limited climatic impact because sulphur was largely fixed in sulphur-bearing pyrrhotite. Other explosive eruptions of large magnitude, such as that which produced the Bishop Tuff, also involved reduced, cool silicic magmas and may also have had negligible long-term (years to centuries) atmospheric effects (Scaillet et al., 1998). This conclusion is supported by evidence that apatites in these magmas are up to seven times richer in Mn than the host 
whole-rock (data from Peng et al., 1997 and Hildreth et al., 1979). Assessing the effects that different eruptions have had on Earth's atmosphere therefore depend on understanding how the redox state of magmas has varied through geological history. Apatite provides a potentially valuable way of assessing this in a range of intermediate to silicic magmas.

600

601 The isotopic record of terrestrial detrital accessory minerals has proved central to many studies of the early evolution of the continental crust (e.g. Eiler, 2007; Kemp et al., 2006, 2007; Hawkesworth et al., 2010; Wilde et al., 2001). Detrital accessory minerals may also offer insights into the redox states of magmas lost from the geological record, such as those of the Archean and Hadean eons (Lee et al., 2010; Trail et al., 2011). Like zircon, apatite is a prevalent and robust accessory phase in the detrital record (Morton and Yaxley, 2007; Corfu and Easton, 2001; Chamberlain and Browning, 2001), and is commonly preserved as an inclusion phase in a range of host minerals in even the most re-worked sediments. Although the context of the original host rocks is now lost, the observed magnitude of variation in $\mathrm{Mn}$

610 concentrations in apatites from oxidised and reduced magmas means it should be possible to 611 constrain the redox condition of host magmas from detrital grains alone.

\section{Acknowledgements}

614 AM is grateful to NERC for a CASE studentship and acknowledges the support of the British 615 Geological Survey for a BUFI grant to meet the costs of analytical work. NERC is also 616 thanked for use of the Edinburgh Ion Microprobe Facility. John Craven has provided valuable 617 assistance during ion probe analyses. Chris Hayward is thanked for his assistance with 618 electron probe analyses of apatite and Mike Hall for support with zircon mounts and thin 619 section preparation. Ian Butler provided valuable assistance with reflected light microscopy. 620 We thank Godfrey Fitton and Nigel Harris for helpful comments on early drafts of the 
manuscript. Calvin Miller, Antony Burham and John Dilles have provided helpful reviews that have greatly improved the manuscript. We also thank Ed Ripley for his editorial handling.

624

625

Figures

626

627

Fig. 1 a) Regional distribution of major Scottish plutons. Abbreviations: HBF - Highland

Boundary Fault, IS - Iapetus Suture. b) Map of the Criffell pluton. Paler shading reflects increasing whole-rock $\mathrm{SiO}_{2}$. Compositional contours are from Stephens and Halliday (1980). Zone lithologies as follows (minerals listed in order of increasing modal abundance): 1) clinopyroxene-biotite-hornblende granodiorite; 2) biotite-hornblende granodiorite; 3) biotite granite; 4) biotite-muscovite granite 5) muscovite-biotite granite (Stephens et al., 1985). Black points denote sample sites with the following sample numbers: Zone 1 - AM0917, Zone 2 - AM0918, Zone 3 - AM0921, Zone 4 - AM0922.

635

636

Fig. 2 Back-scatter Scanning Electron Microscope (SEM) image of magnetite with trellis-like oxidation-exsolution lamellae from Zone 3 of the Criffell pluton. This is likely to reflect exsolution of magnetite and ulvospinel, with subsequent oxidation of ulvospinel to ilmenite (Haggerty, 1991). Exsolution lamellae are not seen in magnetite from other, less silicic zones.

Fig. 3 a) Mn concentrations (re-calculated as ppm) in zones 1 to 4 of the Criffell pluton.

642 Whole-rock Mn concentrations decrease from outer (Zone 1) to inner (Zone 4) zones while apatite Mn concentrations increase, reflecting increasingly compatible substitution of Mn into apatite. b) $\mathrm{Fe}_{2} \mathrm{O}_{3}$ concentrations in zones 1 to 4 of the Criffell pluton. Fe-poor host minerals are zircon, feldspar and quartz, Fe-rich minerals are biotite and hornblende. The general 
646 decrease in whole-rock $\mathrm{Fe}^{3+}$ towards more silicic zones is evident along with a general 647 increase in apatites hosted by Fe-poor minerals. Apatites hosted by Fe-rich minerals have 648 higher Fe concentrations due to secondary fluorescence during EPMA analysis. The data for 649 apatites hosted by $\mathrm{Fe}$-poor minerals exclude four anomalously high values. c) $\mathrm{MnO} / \mathrm{FeO}_{\text {Total }}$ 650 in zones 1 to 4 of the Criffell pluton. Apatite values are for those hosted in Fe-poor minerals 651 only, and exclude the same anomalous values as in (b). EPMA $2 \sigma$ analytical error on Mn concentrations in apatite is $\sim \pm 150 \mathrm{ppm}$.

653

654 Fig.4 Calculated Eu anomalies $\left(\mathrm{Eu} / \mathrm{Eu}^{*}=\mathrm{Eu}_{N} /\left(\mathrm{Sm}_{\mathrm{N}} \times \mathrm{Gd}_{\mathrm{N}}\right)^{1 / 2}\right)$ for apatites from zones 1 to 4 655 of the Criffell pluton.

656

657

Fig. 5 a) Average chondrite-normalised zircon REE profiles for zones 1 to 4 of the Criffell 658 pluton. b) Zircon Ce anomalies Ce/Ce* $=\mathrm{Ce} /\left(\mathrm{La}_{\mathrm{N}} \times \operatorname{Pr}_{\mathrm{N}}\right)^{1 / 2}$ for individual zircon crystals from 659 zones 1 to 4 of the Criffell pluton. Median values for each zone are represented by star 660 symbols and error bars represent interquartile ranges. Compositions determined using a 661 Cameca 4f ion microprobe at the University of Edinburgh.

662

663 Fig. 6 Apatite $\mathrm{MnO} /$ whole-rock $\mathrm{MnO}$ vs. Whole-rock $\mathrm{SiO}_{2}$ for different suites of granitic $664\left(\mathrm{SiO}_{2}>63 \mathrm{wt} \%\right)$ rocks. Increasing apatite/ whole-rock Mn ratios in more silicic samples are 665 evident. Samples that have ratios $<5$ when whole-rock $\mathrm{SiO}_{2}>70 \%$ (e.g. samples from 666 Belousova et al., 2001; Chu et al., 2009) are typically from fractionated I-type granites with 667 only minor volumes of assimilated reduced sedimentary rocks. The redox state of these 668 magmas is likely to have remained more oxidising than in S-type magmas.

669 
670 Fig. 7 Oxygen fugacity values calculated using the expression of Trail et al., (2011) plotted as

$671 \log$ unit deviations from the fayalite-magnetite-quartz (FMQ) buffer (Frost, 1991) ( $\triangle \mathrm{FMQ}$ ).

672 Horizontal lines represent median values and the upper and lower box boundaries represent

673 interquartile ranges. Error bars represent 1.5 times the interquartile range and data points

674 outside of these regions are considered outliers. Upper mantle oxygen fugacities are from

675 Delano, 2001; Mallmann and O’Neill, 2009 and Frost and McCammon, 2008.

676

677 Fig. $8 \mathrm{La} / \mathrm{Sm}$ and $\mathrm{Ce} / \mathrm{Sm}$ plotted against Ce/Ce* for zircons from the Criffell pluton (this 678 study) and Bishop Tuff (Reid et al., 2011). A clear power law relationship is evident between $679 \mathrm{Ce} / \mathrm{Ce}^{*}$ and $\mathrm{La} / \mathrm{Sm}$, suggesting that variations in $\mathrm{Ce} / \mathrm{Ce}^{*}$ and calculated $\mathrm{fO}_{2}$ are more strongly 680 dependent on relative changes in the concentrations of La and Pr rather than Ce.

681

682 Fig. 9 Average apatite Mn concentrations for different volcanic eruptions (black symbols) 683 against independent estimates of oxygen fugacity $\left(f \mathrm{O}_{2}\right)$. Oxygen fugacities have been 684 calculated using the NNO buffer equation of Eugster and Wones (1962) at the eruption 685 temperatures listed by Scaillet et al., (1998) for each volcano. For the Criffell samples (grey 686 symbols), redox estimates are from Stephens et al., (1985) and converted to $\mathrm{fO}_{2}$ using 687 temperature estimates obtained from Ti-in-zircon thermometry (Table 2). Horizontal error 688 bars represent 1 standard deviation in average apatite Mn concentrations. Apatite data 689 together with sample details can be found in Peng et al. (1997) and references therein, redox 690 data are from Scaillet et al., (1998) and references therein. Numbers adjacent to data points 691 denote the following intrusions and volcanoes: 1 - Criffell granodiorite (Zone 1), 2 - Mount 692 St Helens (May 18, 1980 eruption), 3 - Láscar, 4 - Tambora, 5 - Krakatau, 6 - El Chichón, 7 693 - Pinatubo, 8 - Bishop Tuff, 9 - Santa Maria, 10 - Criffell granite (Zone 4). See Appendix 1 
694 in Peng et al., (1997) for sample details. Eruption temperatures reported in Supplementary 695 Material 5.

696

697 Supplementary Material 1: Whole-rock compositions from Stephens and Halliday (1980) and 698 apatite saturation temperatures

699 Supplementary Material 2: Compositional traverses of apatite crystals in Zones 1 and 2

700 Supplementary Material 3: Ims-4f SIMS apatite analyses reported in ppm

701 Supplementary Material 4: Fractional crystallisation models

702 Supplementary Material 5: Temperature, $\mathrm{SiO}_{2}$ and redox conditions for volcanic samples

703

704

705

REFERENCES CITED

706

707 Annen, C., Blundy., J. and Sparkes, S.J. (2006) The genesis of intermediate and silicic 708 magmas in deep crustal hot zones. J. Petrol 47, 505-539.

709

710 Arculus, J.R. (2003) Use and abuse of the terms calcalkaline and calcalkalic. J.Pet. 44, 929711935.

712

713 Ballard J.R., Palin, J.M. and Campbell, I.H. (2002) Relative oxidation states of magmas 714 inferred from $\mathrm{Ce}(\mathrm{IV}) / \mathrm{Ce}$ (III) in zircon: application to porphyry copper deposits of northern 715 Chile. Contrib. Min. and Pet. 144, 347-364.

716 
717 Belousova, E.A., Walters, S., Griffin, W.L. and O'Reilly, S.Y. (2001) Trace-element 718 signatures of apatites in granitoids from the Mt Isa Inlier, northwestern Queensland. Aust. J. 719 Earth. Sci. 48, 603-619.

720

721 Belousova, E.A., Griffin, W.L., O’Reilly, S.Y., and Fisher, N.I. (2002) Apatite as an indicator 722 mineral for mineral exploration: trace-element compositions and their relationship to host 723 rock type. J. Geochem. Explo. 76, 45-6.

724

725 Belvin, P.L. (2004) Redox and compositional parameters for interpreting the granitoid 726 metallogeny of Eastern Australia: Implications for gold-rich ore systems. Resour. Geol. 54, $727 \quad 241-252$.

728

729 Binder, B and Keppler, H. (2011) The oxidation state of sulphur in magmatic fluids. Earth $730 \quad$ Planet Sci. Lett. 301, 190-198.

732 Burgisser, A and Scaillet, B. (2007) Redox evolution of a degassing magma rising to the 733 surface. Nature 445, 194-197.

734

735 Burnham, A.D. and Berry, A.J. (2012) An experimental study of trace element partitioning 736 between zircon and melt as a function of oxygen fugacity. Geochim. Cosmochim. Acta 95, $737 \quad 196-212$.

739 Canil, D., O’Neill, H. St.C., Pearson, D.G., Rudnick, R.L., McDonough, W.F., Carswell, 740 D.A. (1994) Ferric iron in peridotites and mantle oxidation states. Earth Planet Sci. Lett. 123, $741 \quad 205-220$. 
743 Canil, D. (1997) Vanadium partitioning and the oxidation state of Archean komatiite 744 magmas. Nature 389, 842-845.

745

746 Carmichael, I.S.E. (1991) The redox state of basic and silicic magmas: a reflection of their 747 source regions? Contrib. Mineral. Petrol. 106, 129-141.

748

749 Carmichael, I.S.E., and Ghiorso, M.S. (1990) The effect of oxygen fugacity on the redox state 750 of natural liquids and their crystallising phases. Rev. Mineral. 24, 191-2012.

751

752 Cao, M., Li, G., Qin, K., Seitmuratova, E.Y. and Liu, Y. (2011) Major and trace element 753 characteristics of apatites in granitoids from Central Kazakhstan: Implications for petrogensis 754 and mineralization. Resour. Geol. 62, 63-83.

755

756

Cerny, P., Meintzer, R.E., Anderson, A.J. (1985) Extreme fractionation in rare-element 757 granitic pegmatites: selected examples of data and mechanisms. Can. Mineralo. 23, 381-421.

758

759

Chamberlain, K.R. and Browning, S.A. (2000) Apatite-feldspar U-Pb thermochronometer: a 760 reliable mid-range $\left(\sim 450^{\circ} \mathrm{C}\right)$, diffusion controlled system. Chem. Geol. 172, 173-200.

761

762 Cherniak, D.J. and Watson, B.W. (2003) Diffusion in zircon. In Zircon (eds. Hanchar, J.M., 763 and Hoskin, P.W.O) Mineral. Soc. Am, p. 113-139.

764

765 Cherniak, D.J. (2005) Uranium and manganese diffusion in apatite. Chem. Geol. 219, 297766308. 
768 Chesner, C.A. (1998) Petrogenesis of the Toba tuffs, Sumatra, Indonesia. J. Petrol. 39, 397-

769

770

771

772

773

774

775

776

777

778

779

780

781

782

783

784

785

786

787

788

789

790 438.

Chu, M.F., Wang K.L., Griffin, W.L., Chung, S.L., O’Reilly, S.Y., Pearson, N.J., Lizuka, Y, (2009) Apatite composition: Tracing petrogenetic processes in Transhimalayan granitoids. J. Petrol. 50, 1829-1855.

Claiborne, L.L., Miller, C.F., Wooden, J.L. (2010) Trace element composition of igneous zircon: a thermal and compositional record of the accumulation and evolution of a large silicic batholith, Spirit Mountain, Nevada. Contrib. Mineral. Petrol. 160, 511-531.

Colombini, L.L., Miller, C.F., Gualda, G.A.R, Wooden, J.L., Miller, J.S. (2011) Sphene and zircon in the Highland Range volcanic sequence (Miocene, southern Nevada, USA): elemental partitioning, phase relations, and influence on evolution of silicic magma. Contrib. Mineral. Petrol. 102, 29-50.

Corfu, F. and Easton, R.M. (2001) U-Pb evidence for polymetamorphic history of Huronian rocks within the Grenville front tectonic zone east of Sudbury, Ontario, Canada: Chem. Geol. 172, 2979-2995.

Dawson, J. and Hinton, R. (2003) Trace-element content and partitioning in calcite, dolomite, and apatite in carbonate, Phalaborwa, South Africa. Min. Mag. 67, 921-930. 
Delano, J.W. (2001) Redox history of the Earth's interior since 3900 Ma: implications for

793

794 Dilles, J.H. (1987) Petrology of the Yerington batholith, Nevada: Evidence for evolution of 795 porphyry copper ore fluids. Econ Geol 82, 1750-1789.

796

797 Eiler, J. M. (2007) On the origins of granites. Science 315, 951-952.

798

799 Eugster, H. P. and Wones, D. R. (1962) Stability relations of the ferruginous biotite, annite. J. $800 \quad$ Petrol. 3, 82-125.

801

802 Ewart, A. and Griffin, W.L. (1994) Application of Proton-Microprobe Data to Trace-Element 803 Partitioning in Volcanic-Rocks. Chem. Geol. 117, 251-284.

804

805 Ferry, J.M., and Watson, E.B. (2007) New thermodynamic models and revised calibrations 806 for the Ti-in-zircon and Zr-in-rutile thermometers. Contrib. Mineral. Petrol. 154, 429-437.

807

808 Finch, R.J., Hanchar., J.M., Hoskin, P.O. and Burns, P.C. (2001) Rare-earth elements in 809 synthetic zircon: Part 2. A single-crystal X-ray study of xenotime substitution. Am Mineral. 810 86, 681-689.

811

812 Frost, D.J. and McCammon, C.A. (2008) The redox state of Earth's mantle. Ann. Rev. Earth 813 Planet. Sci. 36, 289-420.

814 
815 Frost, R.B. (1991) Introduction to oxygen fugacity and its petrological importance. In:

816 Lindsley, D.H. (ed): Oxide minerals: petrologic and magnetic significance. Rev. Mineral 25, $817 \quad 1-8$

818

819 Ghiorso, M.S. and Gualda, G.A.R. (2013) A method for estimating the activity of titania in 820 magmatic liquids from the compositions of existing rhombohedral and cubic iron-titanium oxides. Contrib Mineral Petrol 165, 73-81.

822

823 Gill, J.B. (1981) Orogenic Andesites and Plate Tectonics. Springer.

824

825 Gonnerman, H.M. and Manga, M. (2003) Explosive volcanism may not be an inevitable 826 consequence of magma fragmentation. Nature 426, 423-435.

827

828

Haggerty, S. (1991) Oxide textures. A mini atlas. In: Lindsley, D.H. (eds) Oxide minerals: petrologic and magnetic significance. Min Soc Am, Rev Mineral 25, Chapter 5: 129-219

830

831 Hanchar, J.M., Finch, R.J., Hoskin, P.O., Watson, E.B., Cherniak, D.J. and Mariano, A.N. 832 (2001) Rare earth elements in synthetic zircon: Part 1. Synthesis, and rare-earth element and 833 phosphorus doping of zircon. Am. Mineral. 86, 667-680.

835 Hanchar, J.M and van Westrenen, W. (2007) Rare earth element behaviour in zircon-melt 836 systems. Elements 3, 37-42.

837

838 Harrison, T.M. and Watson, E.B. (1984) The behaviour of apatite during crustal anatexsis: 839 equilibrium and kinetic considerations. Geochim. Cosmochim. Acta 48, 1467-1477. 
841 Hawkesworth, C. J., Dhuime, B., Pietranik, A.B., Cawood, P.A., Kemp, A.I.S., and Storey,

842 C.D. (2010) The generation and evolution of the continental crust: Journal of the Geological

843 Society 167, p. 229-248.

844

845 Hayden L.A., and Watson, E.B. (2007) Rutile saturation in hydrous silicate melts and its 846 bearing on Ti-thermometry of quartz and zircon. Earth Planet. Sci. Lett. 258, 561-568.

847

848 Hayden, LA., Watson, E.B., Wark, D.A. (2008) A thermobarometer for sphene (titanite).

849 Contrib Mineral Petrol 155, 529-540.

850

851 Hildreth, W. (1979) The Bishop Tuff: Evidence for the origin of compositional zonation in 852 silicic magma chambers. Geol. Soc. Am. Special Papers 180, 43-76.

853

854 Hinton, R.W. and Upton, B.G. (1991) The chemistry of zircon: Variations within and 855 between large crystals from syenite and alkali basalt xenoliths. Geochim. Cosmochim Acta $856 \mathbf{5 5}, 3287-3302$.

857

858 Holloway, J.R. (2004) Redox in seafloor basalts: possible insights into silicic hydrothermal 859 systems. Chem Geol 210 p. 225-230.

860

861 Hoskin, P.W., Kinny, P.D., Wyborn, D., et al., (2000) Identifying accessory mineral 862 saturation during differentiation in granitoid magmas: an integrated approach. J. 863 Petrol.41,1365-1396. 
865 Hoskin, P.W. and Schalegger, U. (2003) The composition of zircon and igneous and 866 metamorphic petrogensis. In, Hanchar, J.M. and Hoskin, P.W.O. (eds) Zircon. Rev. Mineral. 867 Geochem. 53, 27-62.

868

869 Hughes, J.M., Ertle, A., Bernhardt, H.J., Rossman, R.J. (2004) Mn-rich fluorapatite from 870 Ausria: Crystal structure, chemical analysis, and spectroscopic investigations. Am. Mineral. 871 89, 629-632.

872

873 Huppert, H.E. and Woods, A.W. (2002) The role of volatiles in magma chamber dynamics. $874 \quad$ Nature 420, 493-495.

875

876 Ishihara, S. (1977) The magnetite-series and ilmenite-series granitic rocks. Mining Geology, 877 27, p. 293-305.

878

879 Ishihara, S. (1981) The granitoid series and mineralization. Econ. Geol. $75^{\text {th }}$ Anniversary 880 Volume, p. 458-484.

881

882 Ishihara, S. (2004) The redox state of granitoids relative to tectonic setting and earth history: 883 The magnetite-ilmenite series 30 years later. Trans.R Soc. Edin. Earth Sci, 95, 23-33.

884

885 Jain, J.C., Neal, C.R., Hanchar, J.M. (2001) Problems associated with the determination of 886 rare earth elements of a "gem" quality in zircon by inductively coupled mass-spectrometry. 887 Geostandards Newsletter 25, 229-237.

888 
889 Johnson, M.C. and Rutherford, M.J. (1989) Experimentally determined conditions in the Fish 890 Canyon tuff, Colorado, magma chamber. J.Petrol 3, 711-737.

891

892 Kasting, J.F., Eggler, D.H. and Raeburn, S.P. (1993) Mantle redox evolution and the 893 oxidation state of the atmosphere. J. Geol. 101, 245-257.

894

895 Kelly, K.A., and Cottrell, E. (2009) Water and the oxidation state of subduction zone 896 magmas. Science 325, 605-607.

897

898 Kemp, A.I.S., Hawkesworth, C.J., Paterson, B.A., Kinny, P.D. (2006) Episodic growth of the 899 Gondwana supercontinent from hafnium and oxygen isotopes in zircon. Nature 439, 580-583.

900

901 Kemp, A. I. S., Hawkesworth, C.J., Foster, G.L., Paterson, B.A., Woodhead, J.D., Hergt, 902 J.M., Gray, C.M., and Whitehouse M.J. (2007) Magmatic and crustal differentiation history 903 of granitic rocks from Hf-O isotopes in zircon. Science 315, 980-983.

904

905 Latourrette, T.Z., Burnett, D.S. and Bacon, C.R. (1991) Uranium and minor-element 906 partitioning in Fe-Ti oxides and zircon from partially melted granodiorite, Crater Lake, 907 Oregon. Geochim Cosmochim Acta 55, 457-469.

908

909 Lee, C.A., Luffi, P., Le Roux, V., Dasgupta, R., Albaréde, F. and Leeman, W.P. (2010) The 910 redox state of arc magmas using Zn/Fe systematics. Nature 468, 681-685.

911 
912 Llovet, X. and Galan, G. (2003) Correction of secondary X-ay fluorescence near grain

913 boundaries in electron microprobe analysis: Application to thermombarometry of spinel

914 lherzolites. Am Mineral 88, 121-130.

915

916 London, D., Evensen, J.M, Fritz, E., Icehower, J.P., Morgan, G.B. VI., Wolf, M.B. (2001)

917 Enrichment and accommodation of manganese in granite-pegmatite systems. $11^{\text {th }}$ Annual 918 Goldschmidt Conference Abstract 3369.

919

920 Mallmann, G. and O'Neill, H.S.C. (2009) The crystal/melt partitioning of V during mantle 921 melting as a function of oxygen fugacity compared with some other elements (Al, $\mathrm{P}, \mathrm{Ca}, \mathrm{Sc}$, 922 Ti, Cr, Fe, Ga, Y, Zr and Nb). J.Petrol. 50, 1765-1794.

923

924 Mazhari, S.A. and Attar, R.S. (2012) Apatite application to investigate magmatic evolution of 925 Zouzan granites, NE Lut Block. Iranian J. Earth Sci. 4, 61-72.

926

927 Miles, A.J., Graham, C.M., Hawkesworth, C.J., Gillespie, M.R., Hinton, R.W. and EIMF 928 (2013a) Evidence for distinct stages of magma history recorded by the compositions of 929 accessory apatite and zircon. Contrib. Mineral Petrol 166, 1-19.

930

931 Miles, A.J., Graham, C.M., Hawkesworth, C.J., Gillespie, M.R., Dhuime, B. and Hinton, 932 R.W. (2013b) Using zircon isotope compositions to constrain crustal structure and pluton 933 evolution: the Iapetus suture zone granites in Northern Britain. J. Petrol, doi: 934 10.1093/petrology/egt065.

935 
936 Miller, C.F. and Stoddard, E.F. (1981) The role of manganese in the paragenesis of magmatic

937 garnet: An example from the Old Woman-Piute Range, California. J. Geol 89, 233-246.

938

939 Morton, A. and Yaxley, G. (2007) Detrital apatite geochemistry and its application in 940 provenance studies. GSA Special Paper 420, 319-344.

941

942 Nagasawa, H. (1970) Rare earth concentrations in zircons and apatites and their host dacites 943 and granites. Earth Planet. Sci. Lett. 9, 359-364.

944

945 Pan, Y.M and Fleet, M.E. (2002) Compositions of the apatite-group minerals: Substitution 946 mechanisms and controlling factors. In Phosphates: Geochemical, Geobiological, and 947 Materials Importance (eds. Kohn, M.J., Rakovan, J, and Hughes, J.M.) Mineral. Soc. Am. p. $948 \quad 13-49$.

949

950 Pearce N.J.G., Perkins W.T., Westgate J.A., Gorton M.P., Jackson S.E., Neal C.R. and 951 Chenery S.P. (1997) A compilation of new and published major and trace element data for 952 NIS T SRM 610 and NIST SRM 612 glass reference material Geostandards Newsletter. The 953 Journal of Geostandards and Geoanalysis, 21, 115-144.

954

955

Peng, G. Luhr, J.F. and McGee, J.J. (1997) Factors controlling sulphur concentrations in 956 volcanic apatite. Am. Mineral. 82, 1210-1224.

957

958 Piccoli, P.M. and Candela, P.A. (1994) Apatite in felsic rocks: a model for the estimation of 959 initial halogen contents in the Bishop Tuff (Long Valley) and Tuolumne Intrusive Suite 960 (Sierra Nevada Batholith) Magmas. Am J of Sci, 294, 92- 135. 
962 Pidgeon, R.T. and Aftalion, M. (1978) Cogenetic and inherited zircon U-Pb systems in 963 granites: Palaeozoic granites of Scotland and England, in Bowes, D.R., Leake, B.E., Crustal 964 evolution in northwestern Britain and adjacent regions. Geological Journal Special Issues, p. $965 \quad 183-220$.

966

967 Prowatke, S. and Klemme, S. (2006) Trace element partitioning between apatite and silicate 968 melts. Geochim Cosmochim Acta 70, 4,513-4,527.

969

970 Reid, M.R., Vazquez, J.A. and Schmitt, A.K (2011) Zircon-scale insights into the history of a 971 Supervolcano, Bishop Tuff, Long Valley, California, with implications for the Ti-in-zircon 972 geothermometer. Contrib. Mineral Petrol 161, 293-311.

973

974 Riley, J.P. (1958) Rapid analysis of silicate rocks and minerals. Anlaytica Chimica Acta 19, $975 \quad 413-428$.

976

977 Robock, A. (2000) Volcanic eruptions and climate. Rev Geophys. 38, 191-219.

978

979 Ruzika, A., Snyder, G.A., Taylor, L.A. (2001) Comparative geochemistry of basalts from the 980 Moon, Earth, HED asteroid, and Mars: implications for the origin of the Moon. Geochim. 981 Cosmochim Acta 65, 979-997.

982

983 Scaillet, B. and Gaillard, F. (2011) Redox state of early magmas. Nature 480, 48-49. 984 
985 Scaillet, B., Clemente, B., Evans, B.W., Pichavant, M. (1998) Redox control of sulphur 986 degassing in silicic magmas. J. Geophys. Res. 103, 23,937-23,949.

987

988 Sha, L. K. and Chappell, B.W. (1999) Apatite chemical composition, determined by electron 989 microprobe and laser-ablation inductively coupled plasma mass spectrometry, as a probe into 990 granite petrogenesis. Geochim Cosmochim Acta 63, 3861-3881.

991

992 Schreiber, H.D., Merkel, R.C., Schreiber, V.L. and Balazs, G.B. (1987) Mutual interactions 993 of redox couples via electron exchange in silicate melts: Models for geochemical melt 994 systems. J. Geophys. Res. 92, 9233-9245.

995

996 Stephens, W.E. and Halliday., A.N. (1980) Discontinuities in the composition surface of a 997 zoned pluton, Criffell, Scotland. Geol. Soc.Am. Bull. 91, 165-170.

998

999 Stephens, W. E., Whitley, J. E., Thirlwall, M.F. and Halliday, A. N. (1985) The Criffell 1000 zoned pluton: correlated behaviour of rare earth element abundances with isotopic systems. 1001 Contrib. Mineral. Petrol. 89, 226-238.

1002

1003 Streck, M.J. and Dilles, J.H. (1998) Sulfur evolution of oxidised arc magmas as recorded in 1004 apatite from a porphyry copper batholith. Geology 26, 523-526.

1005

1006 Takagi, T. (2004) Origin of magnetite- and ilmenite-series granitic rocks in the Japan Arc. 1007 Am J Sci 304, 169-202.

1008 
1009 Thomas, J.B., Watson, E.B., Spear, F.S., Shemella, P.T., Nayak, S.K., Lanzirotti, A. (2010)

1010 TitaniQ under pressure: the effect of pressure and temperature on the solubility of Ti in

1011 quartz. Contrib Mineral Petrol 160, 743-759.

1012

1013 Trail, D., Watson, B.E. and Tailby, N.D. (2011) The oxidation state of Hadean magmas and 1014 implications for early Earth's atmosphere. Nature 480, 79-81.

1015

1016 Trail, D., Watson, B.E. and Tailby, N.D. (2012) Ce and Eu anomalies in zircon as proxies for 1017 the oxidation state of magmas. Geochim. Cosmochim. Acta 97, 70-87.

1018

1019 Van Hoose, A.E., Streck, M.J., Pallister, J.S. and Wälle, M. (2013) Sulfur evolution of the 1020 1991 Pinatubo magmas based on apatite. J.Volcan. Geotherm. Res. 257, 72-89.

1021

1022 Wark, D.A. and Watson, E.B. (2006) TitaniQ: a titanium-in-quartz geothermometer. Contrib 1023 Mineral Petrol 152:743-754.

1024

1025 Weill, D.F. and Drake, M.J. (1973) Europium anomaly in plagioclase feldspar: Experimental 1026 results and semi-quantitative model. Science 180, 1059-1060.

1027

1028 Wiedenbeck, M., Hanchar, J.M., Peck, W.H., Sylvester, P., Valley, J., Whitehouse, M., 1029 Kronz, A., Morishita, Y., Nasdala, L. et al., (2004) Further characterization of the 91500 1030 zircon crystal. Geostandards and Geoanalysis 28, 9-39.

1031 
1032 Wilde, S.A., Valley, J.W., Peck, W.H and Graham, C.M. (2001) Evidence from detrital 1033 zircon for the existence of continental crust and oceans on Earth 4.4 Gyr Ago. Nature 409, $1034 \quad 175-178$.

1035

1036 Wones, D.R. (1989) Significance of the assemblage titanite + magnetite + quartz in granitic 1037 rocks. Am Mineral 74, 744-749.

1038

1039 Wood, B.J. and Wade, J. (2013) Activities and volatiles of trace components in silicate melts:

1040 a novel use of metal-silicate partitioning data. Contrib. Mineral. Petrol. 166, 911-921.

1041

1042 Xirouchakis, D., Lindsey, D.H. and Andersen, D.J. (2001) Assemblages with titanite $1043\left(\mathrm{CaTiOSiO}_{4}\right), \mathrm{Ca}-\mathrm{Mg}-\mathrm{Fe}$ olivine and pyroxenes, Fe-Mg-Ti oxides, and quartz: Part I. Theory. 1044 Am Mineral 86, 747-753.

1045 
Table 1 -Element concentrations in apatite. Electron probe (Cameca SX-100) analyses (black) reported as ppm and calculated from

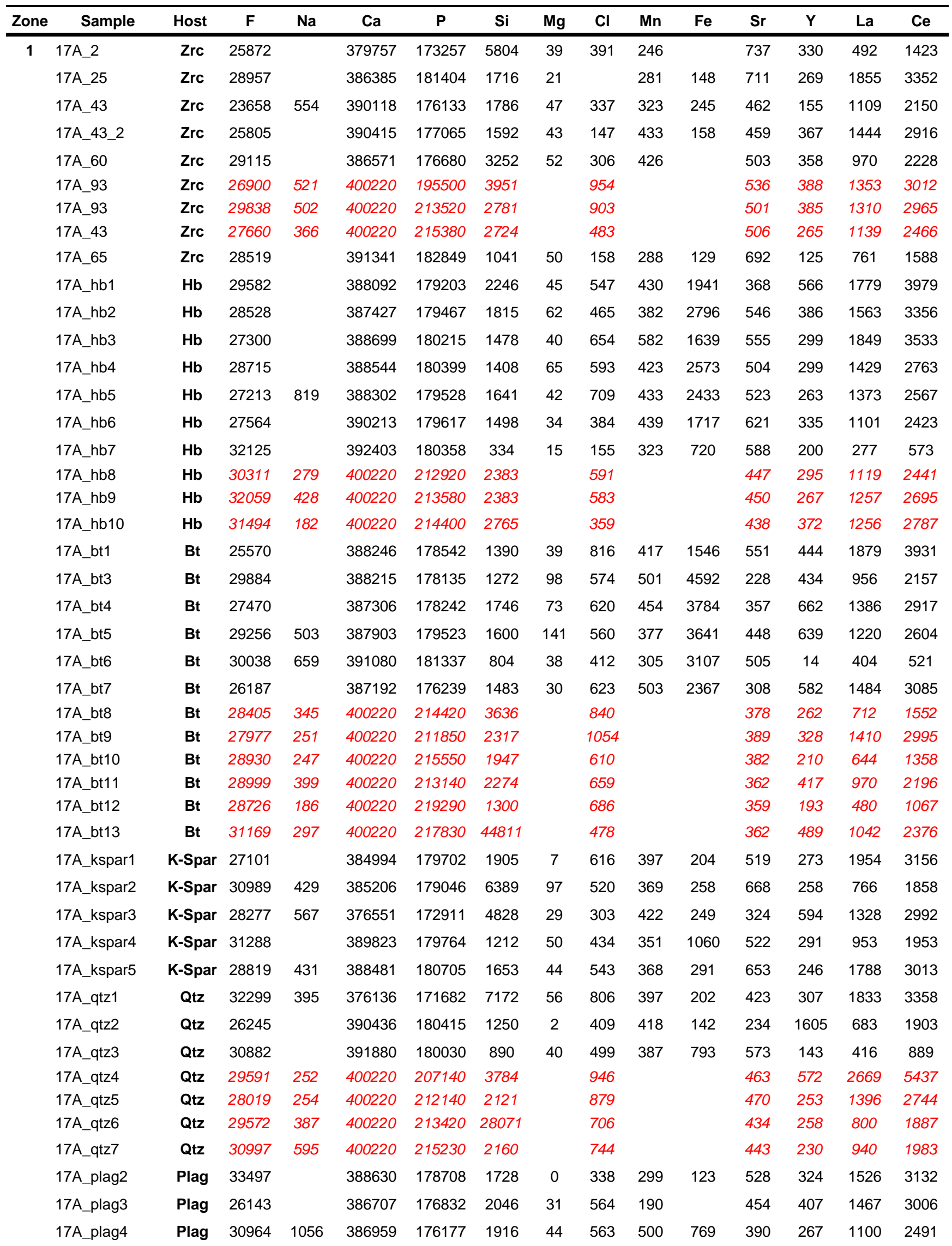


Table 2 - Ims-4f SIMS zircon REE concentrations (ppm)

\begin{tabular}{|c|c|c|c|c|c|c|c|c|c|c|c|}
\hline Zone & Sample & La & $\mathrm{Ce}$ & $\mathrm{Pr}$ & Nd & $\mathrm{Sm}$ & Eu & Gd & $\mathrm{Tb}$ & Dy & Ho \\
\hline 1 & $17 \_9$ & 0.16 & 42.2 & 0.19 & 3.8 & 4.1 & 1.7 & 15.4 & 6.0 & 61 & 24 \\
\hline 1 & $17 \overline{12}$ & 0.15 & 23.9 & 0.12 & 1.6 & 1.8 & 0.5 & 5.7 & 2.2 & 26 & 11 \\
\hline 1 & 17_60 & 0.27 & 48.0 & 0.34 & 4.6 & 5.5 & 2.0 & 25.8 & 8.5 & 92 & 35 \\
\hline 1 & 17_93 & 0.18 & 44.7 & 0.23 & 2.5 & 3.5 & 0.9 & 16.0 & 5.9 & 67 & 26 \\
\hline 1 & 17_94 & 0.18 & 43.9 & 0.33 & 3.9 & 5.1 & 1.4 & 19.5 & 6.2 & 71 & 26 \\
\hline 1 & 17_92 & 0.14 & 47.4 & 0.32 & 3.6 & 5.8 & 1.7 & 24.3 & 8.1 & 86 & 30 \\
\hline 1 & 17_85 & 0.14 & 43.3 & 0.20 & 5.1 & 5.5 & 1.6 & 23.5 & 7.4 & 86 & 29 \\
\hline 1 & 17_63 & 0.04 & 37.2 & 0.10 & 1.7 & 3.4 & 0.8 & 15.6 & 5.6 & 58 & 22 \\
\hline 1 & $17 \quad 68$ & 0.02 & 30.8 & 0.08 & 0.6 & 2.3 & 0.6 & 10.2 & 3.8 & 41 & 17 \\
\hline 2 & 18_10 & 0.05 & 27.3 & 0.06 & 1.1 & 2.4 & 0.6 & 9.2 & 3.5 & 41 & 16 \\
\hline 2 & 18_19 & 0.09 & 25.9 & 0.08 & 1.9 & 1.7 & 0.7 & 7.0 & 3.2 & 38 & 15 \\
\hline 2 & $18 \_16$ & 0.15 & 46.1 & 0.33 & 5.2 & 6.5 & 1.8 & 27.6 & 9.6 & 99 & 35 \\
\hline 2 & 18_35 & 2.33 & 101.7 & 1.73 & 17.6 & 15.0 & 5.3 & 48.6 & 16.4 & 167 & 61 \\
\hline 2 & $18 \_60$ & 0.12 & 36.0 & 0.26 & 3.7 & 6.0 & 1.5 & 20.5 & 6.5 & 72 & 26 \\
\hline 2 & 18_76 & 0.09 & 24.1 & 0.12 & 0.9 & 1.4 & 0.5 & 6.2 & 2.4 & 28 & 12 \\
\hline 2 & 18_83 & 0.08 & 46.5 & 0.29 & 4.0 & 6.2 & 1.2 & 25.4 & 7.7 & 82 & 30 \\
\hline 2 & $18 \_7$ & 0.08 & 35.4 & 0.12 & 1.6 & 3.1 & 0.9 & 14.5 & 5.1 & 56 & 21 \\
\hline 2 & 18_22 & 0.04 & 41.4 & 0.08 & 1.7 & 2.3 & 0.9 & 9.6 & 3.9 & 52 & 20 \\
\hline 2 & $18 \_21$ & 0.14 & 29.2 & 0.10 & 0.7 & 1.2 & 0.5 & 7.1 & 2.3 & 32 & 13 \\
\hline 3 & 21_48 & 0.18 & 63.2 & 0.40 & 3.8 & 3.7 & 0.9 & 16.3 & 5.8 & 76 & 30 \\
\hline 3 & 21_60 & 0.25 & 41.3 & 0.34 & 2.8 & 2.3 & 0.8 & 8.9 & 3.6 & 40 & 16 \\
\hline 3 & 21_73 & 0.01 & 27.0 & 0.07 & 0.8 & 1.5 & 0.7 & 7.5 & 3.3 & 37 & 14 \\
\hline 3 & 21_78 & 0.89 & 35.5 & 0.61 & 4.7 & 3.2 & 0.9 & 9.5 & 4.0 & 44 & 18 \\
\hline 3 & 21_92 & 0.09 & 20.6 & 0.07 & 0.6 & 0.9 & 0.3 & 5.2 & 2.1 & 33 & 15 \\
\hline 3 & 21_69 & 0.07 & 62.5 & 0.12 & 2.0 & 3.4 & 1.0 & 15.4 & 5.8 & 77 & 31 \\
\hline 3 & 21_37 & 0.48 & 37.0 & 0.31 & 2.9 & 2.7 & 1.0 & 10.5 & 3.5 & 45 & 18 \\
\hline 3 & 21_38 & 0.37 & 39.3 & 0.26 & 4.2 & 5.6 & 2.4 & 23.1 & 8.0 & 83 & 31 \\
\hline 3 & $21 \_46$ & 0.21 & 49.0 & 0.15 & 1.5 & 1.8 & 0.8 & 11.9 & 4.4 & 50 & 19 \\
\hline 4 & $22 \_7$ & 0.61 & 24.6 & 0.57 & 5.3 & 4.0 & 1.6 & 14.3 & 5.7 & 59 & 22 \\
\hline 4 & $22 \_62$ & 0.15 & 15.8 & 0.10 & 0.9 & 1.2 & 0.4 & 8.0 & 3.5 & 44 & 19 \\
\hline 4 & 22_92 & 0.30 & 13.8 & 0.19 & 1.4 & 0.9 & 0.5 & 3.3 & 1.9 & 28 & 12 \\
\hline
\end{tabular}




\section{Figure 1}

Click here to download high resolution image

Figure. 1

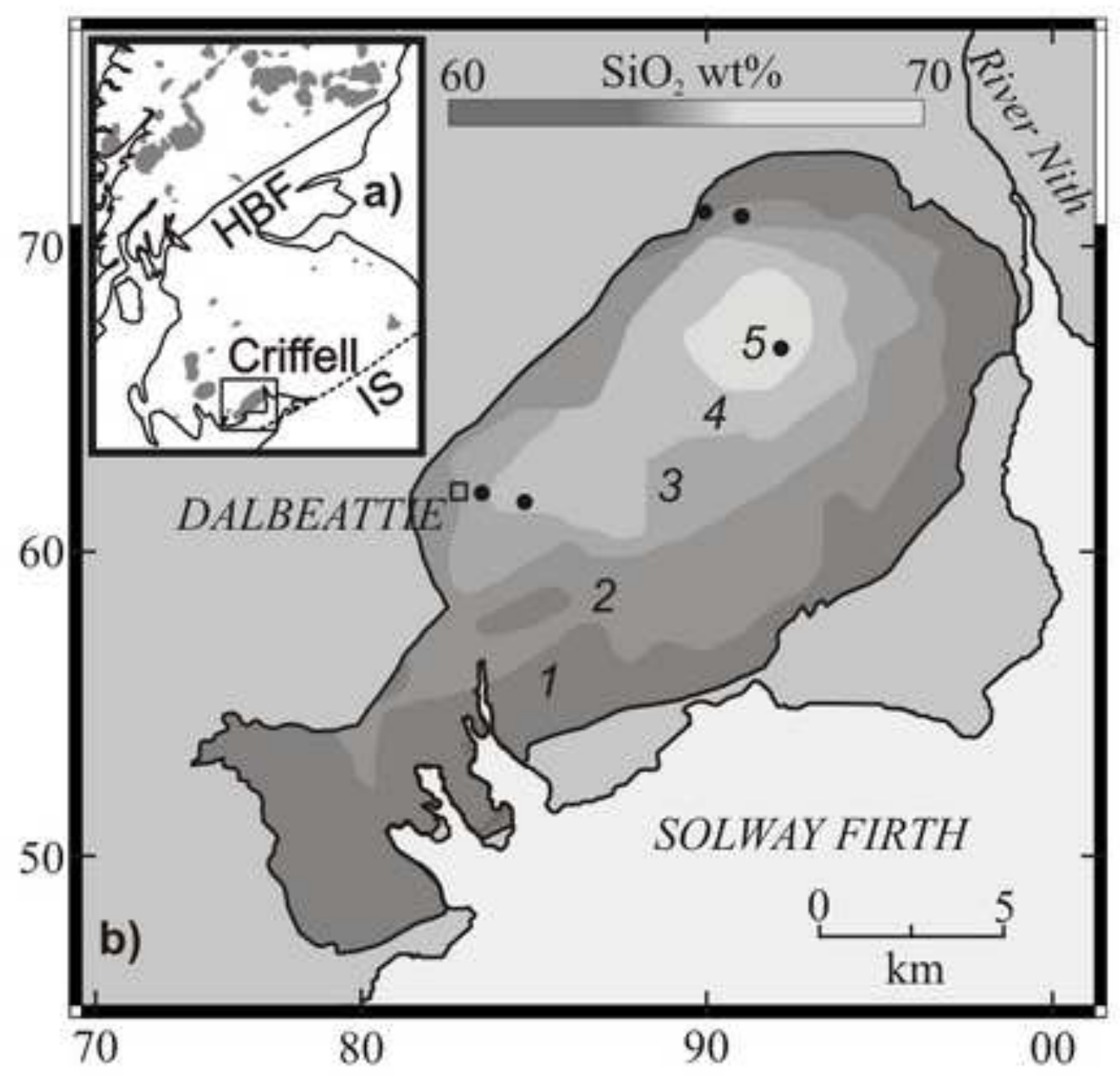




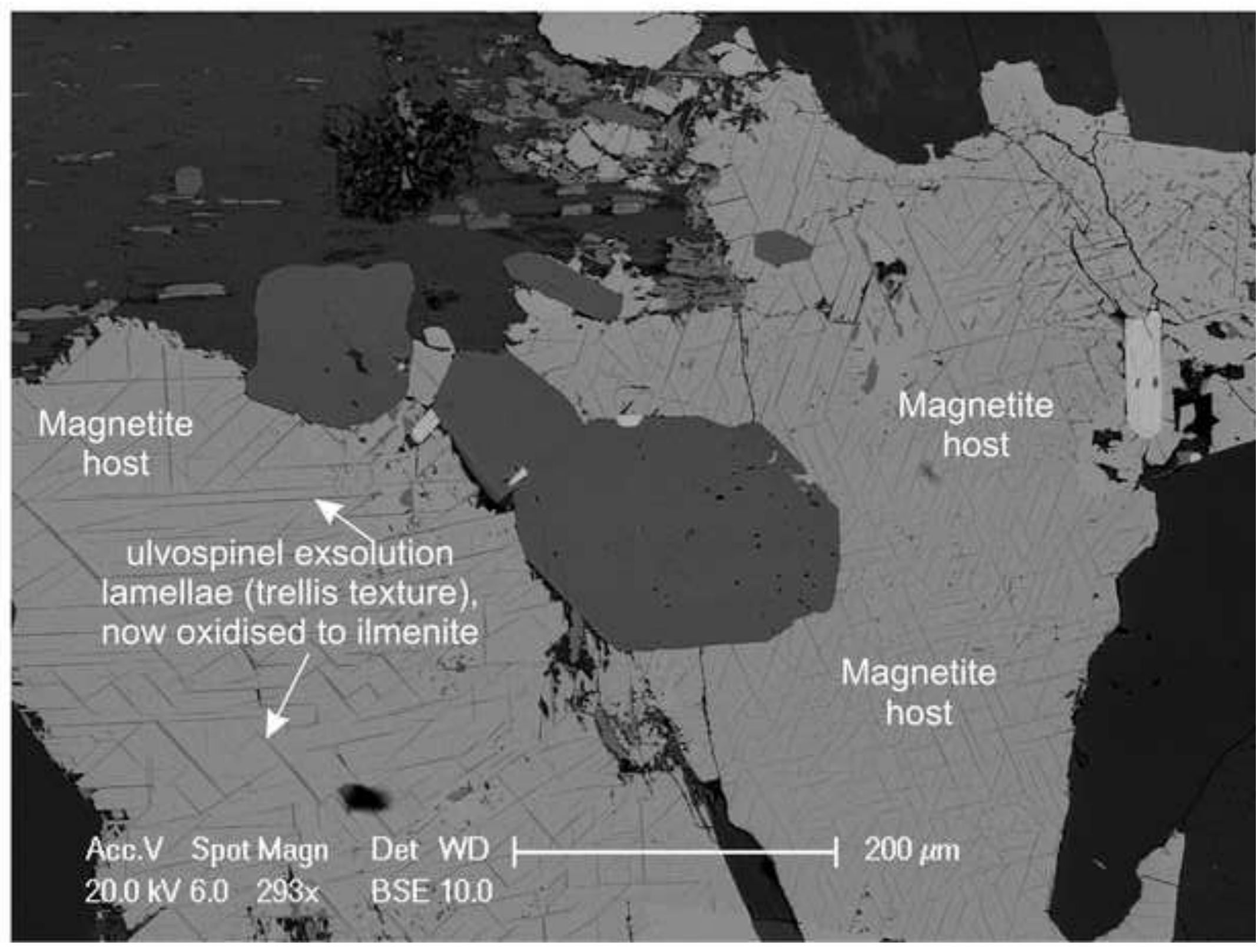




\section{Figure 3}

Click here to download high resolution image

\section{Figure 3}
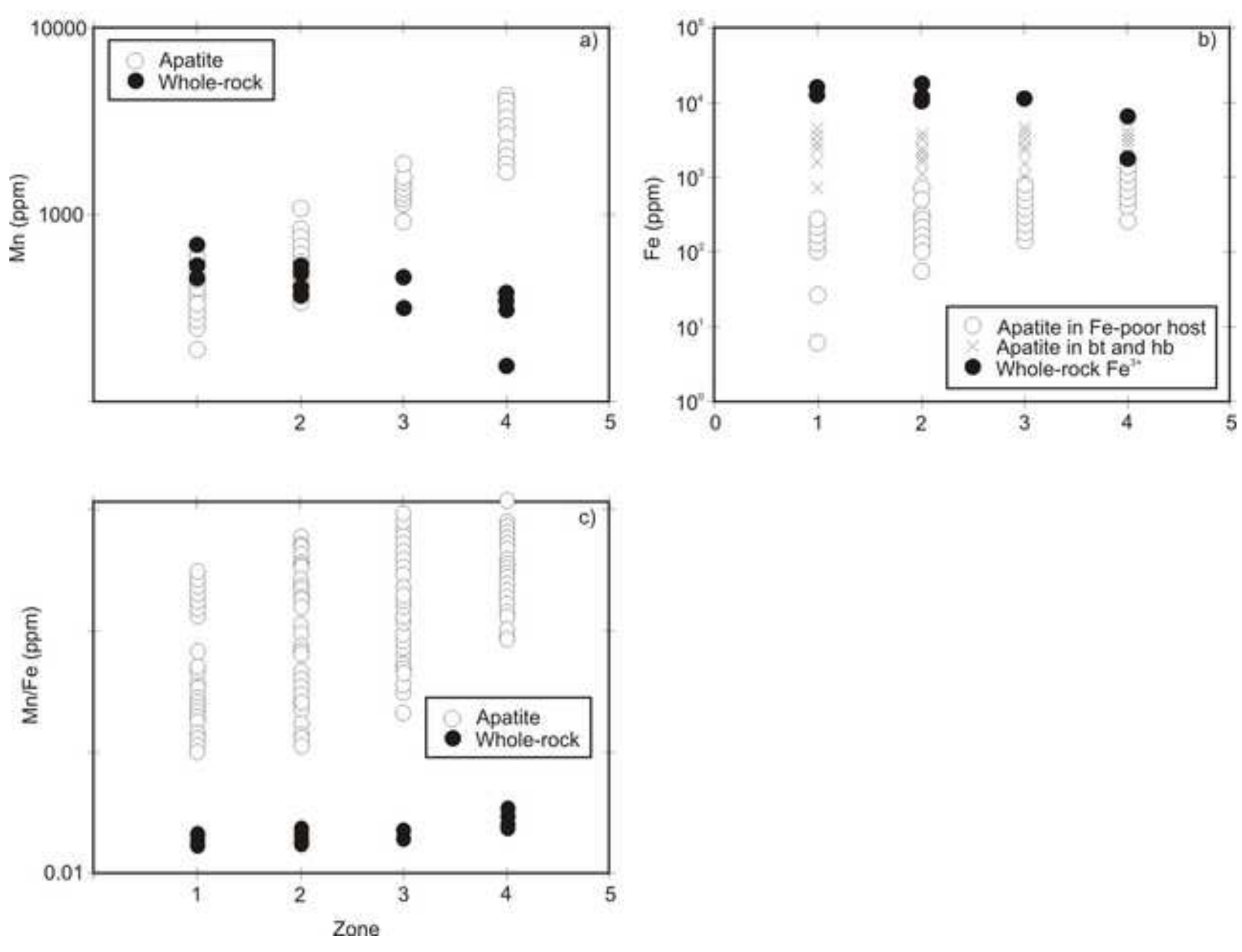

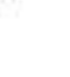

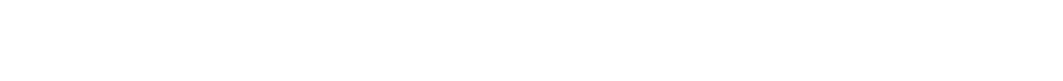


Figure 4
Click here to download high resolution image

Figure 4

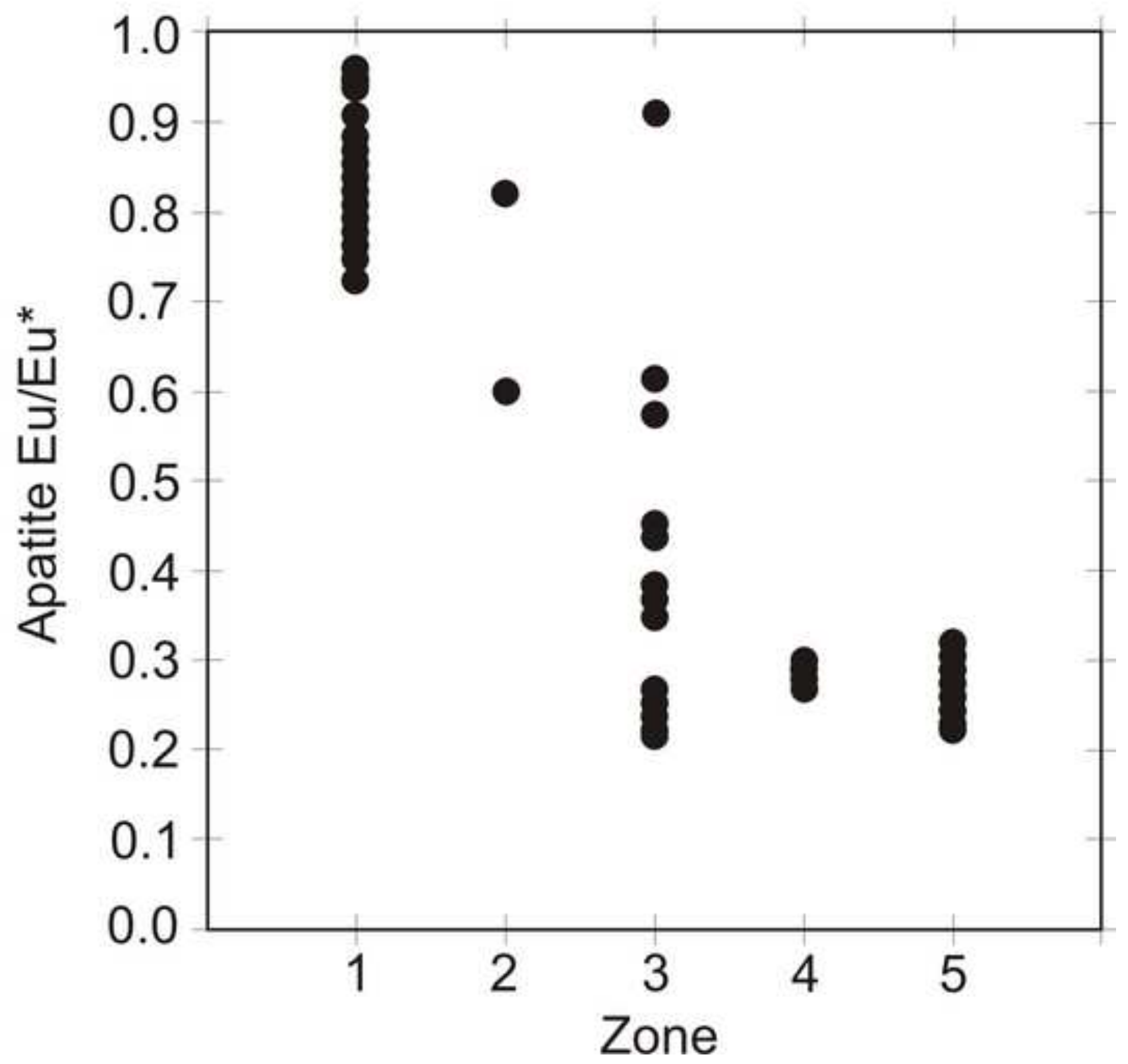


Figure 5
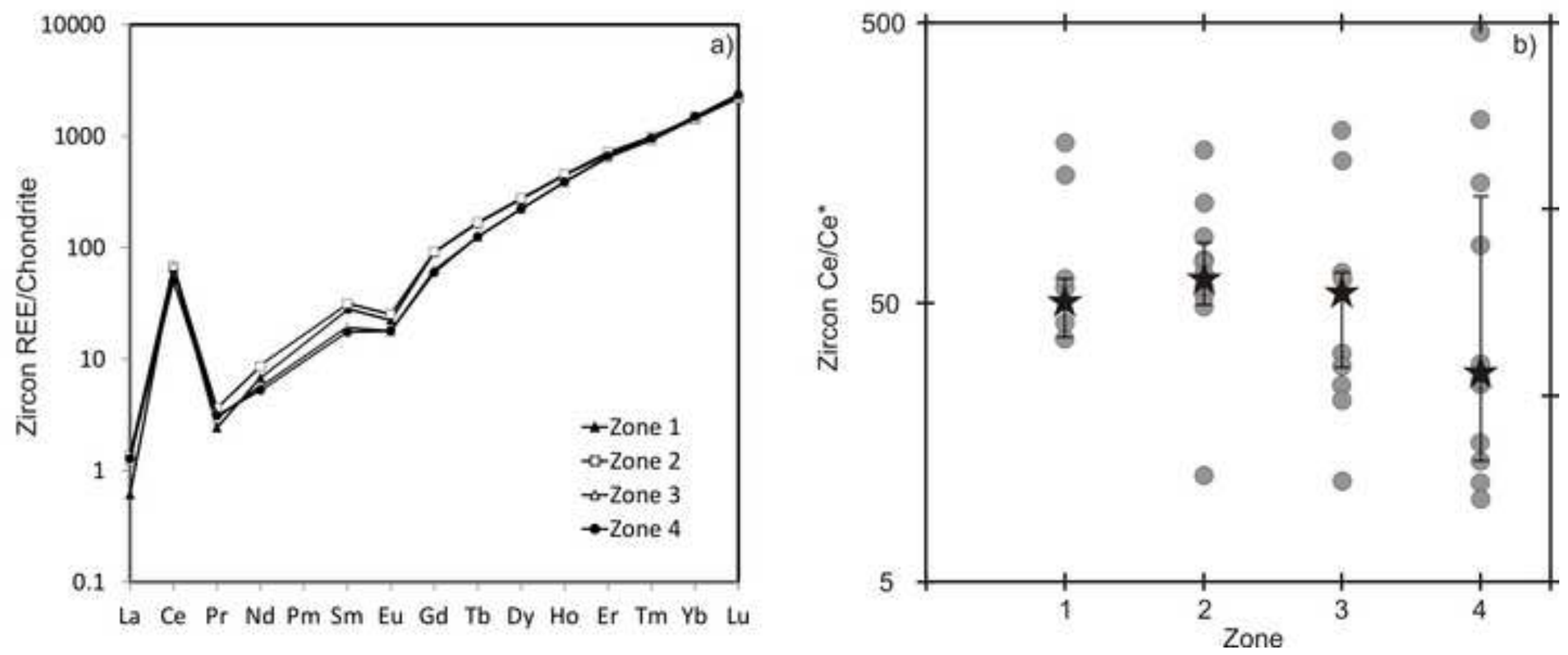


\section{Figure 6}

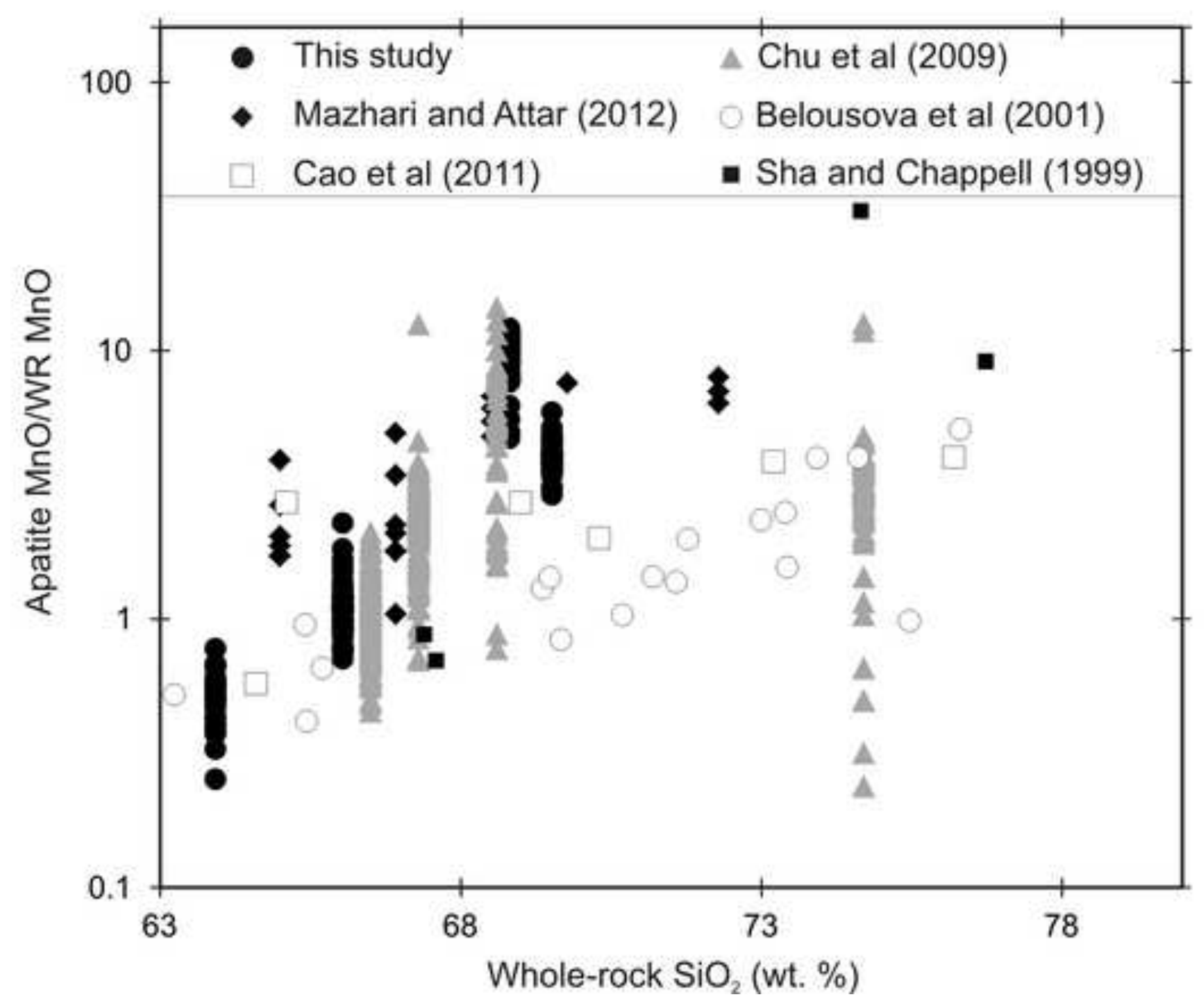


Figure 7

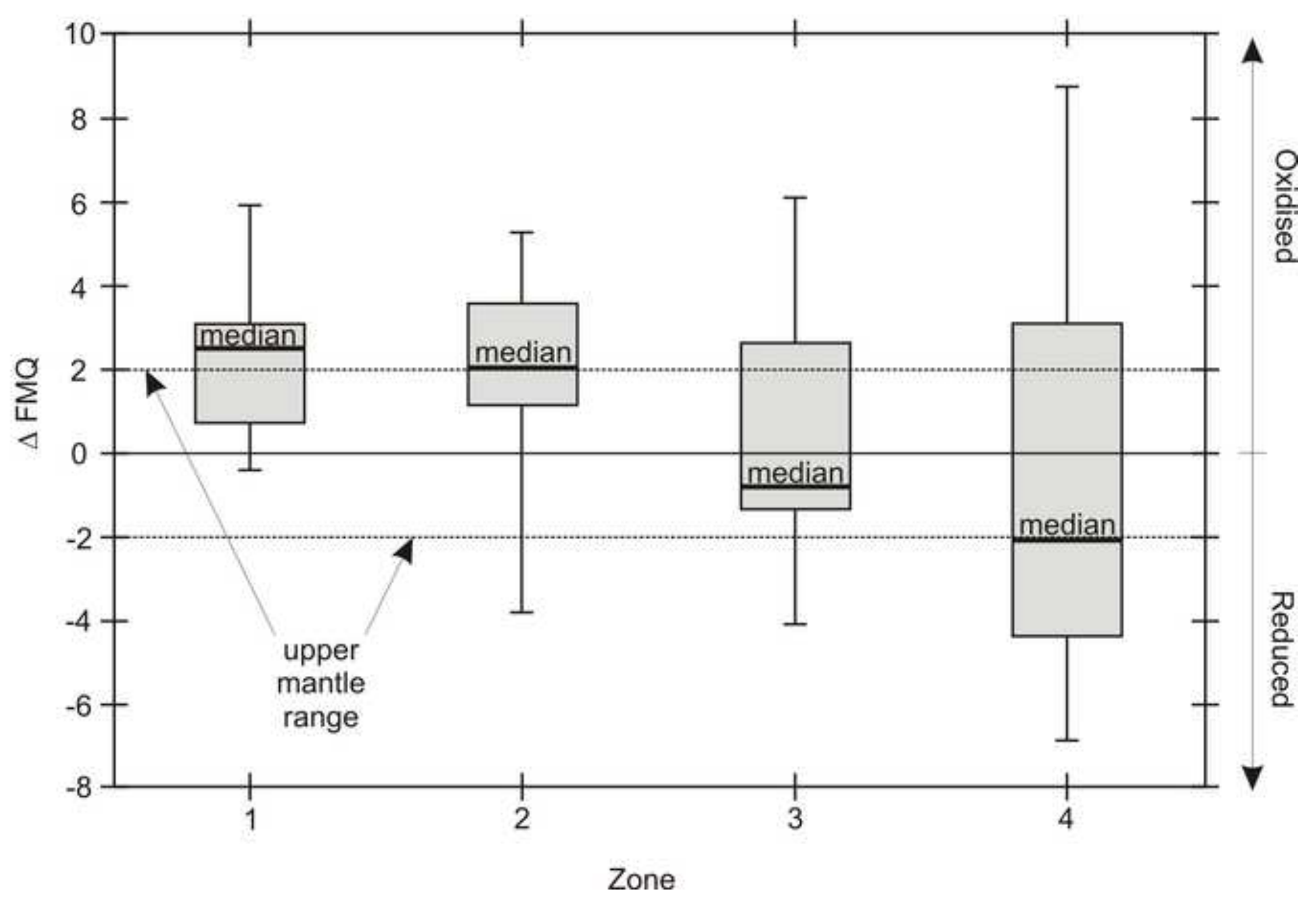




\section{Figure 8}

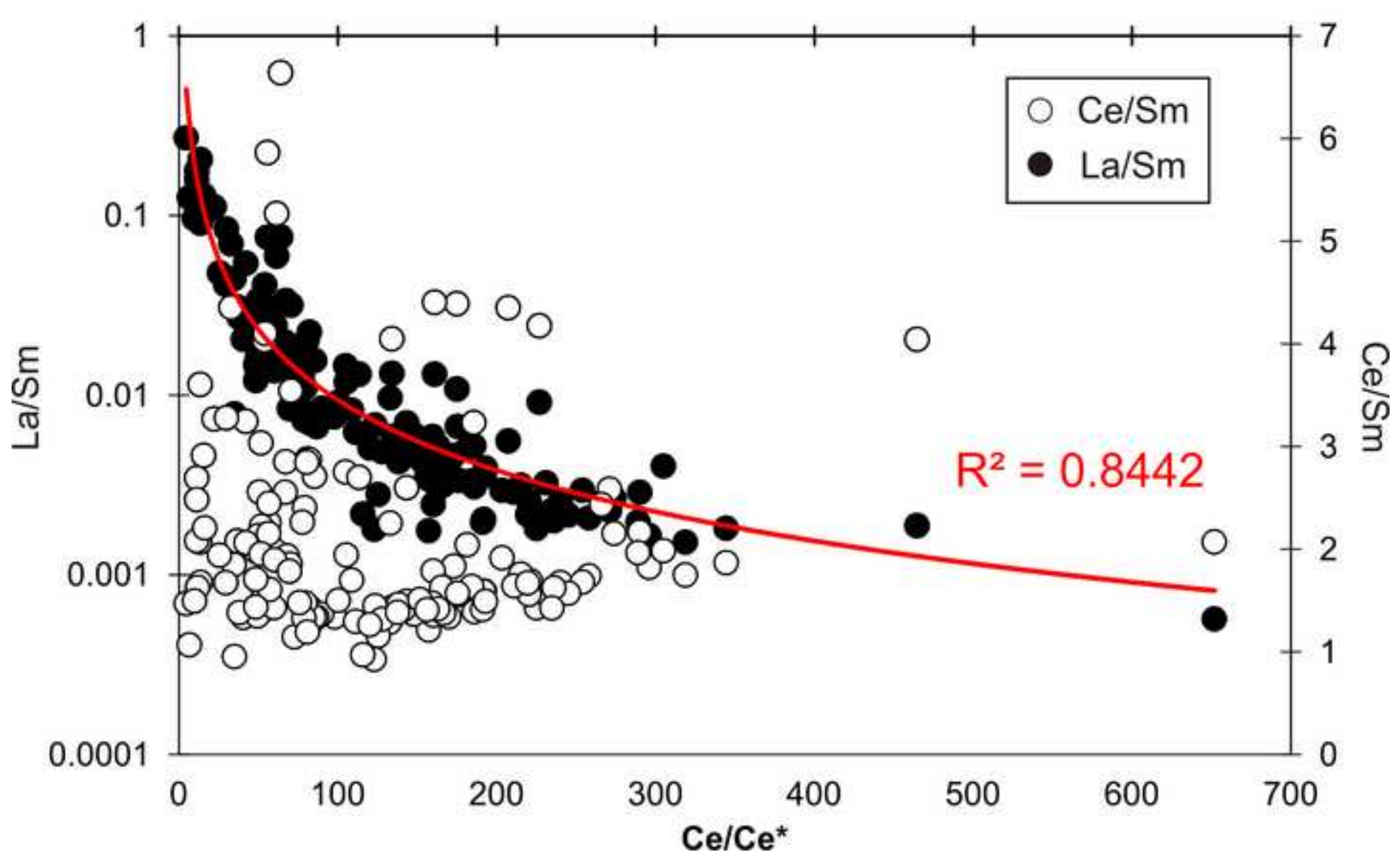




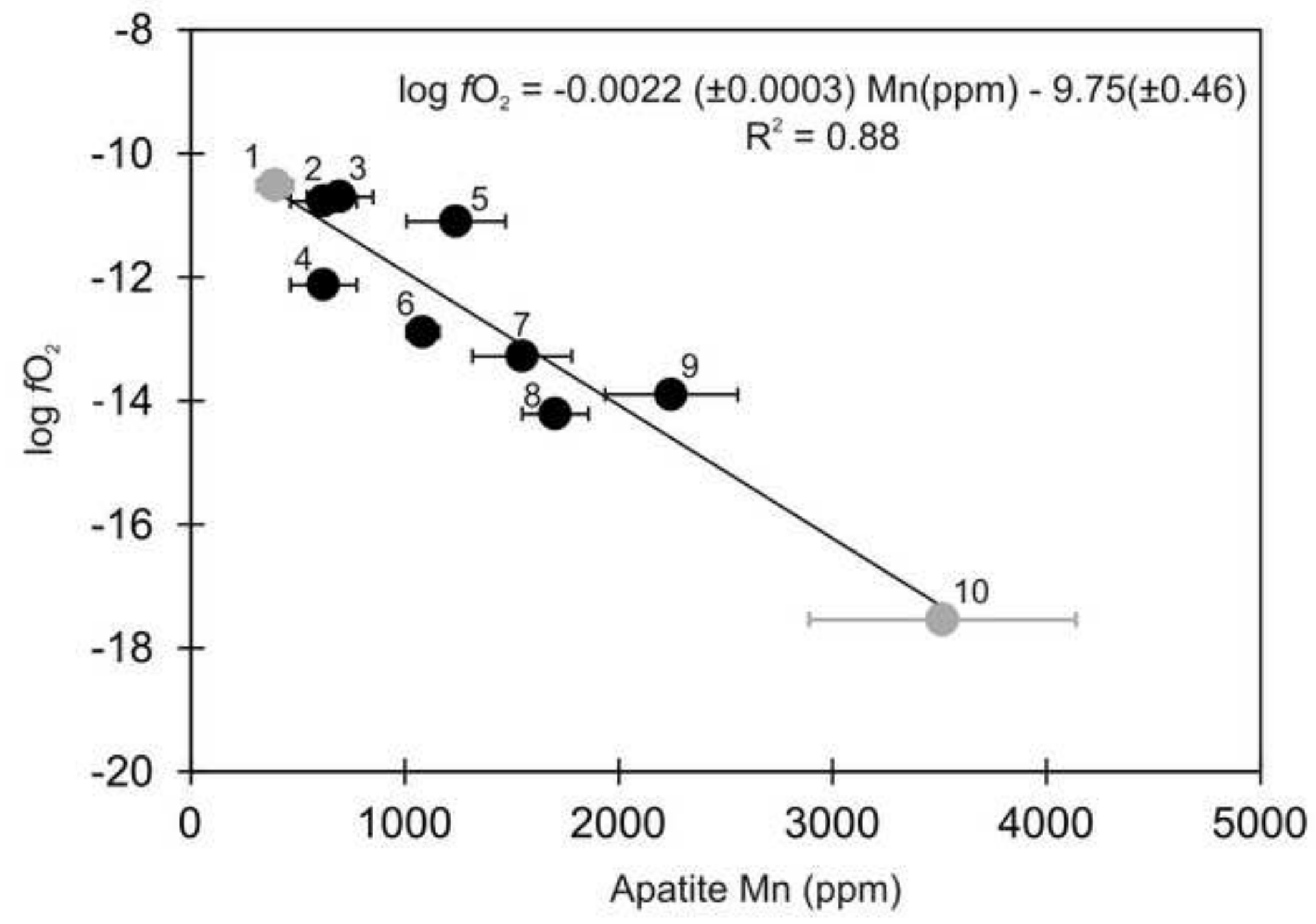


Supplementary Material 1
Click here to download Electronic Annex: Supplementary_1.xls 
Supplementary Material 2
Click here to download Electronic Annex: Supplementary_2..xls 
Supplementary Material 3
Click here to download Electronic Annex: Supplementary_3.xls 
Supplementary Material 5
Click here to download Electronic Annex: Supplementary_5...xIsx

x

Click here to download
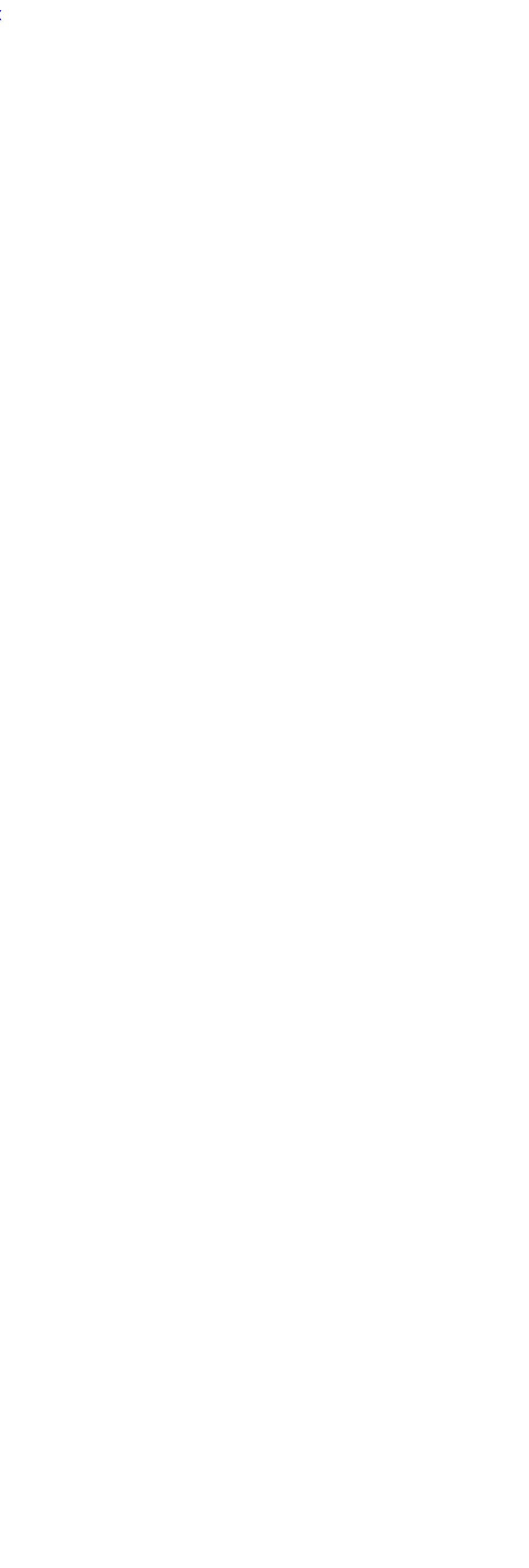